\title{
The Derodontidae, Dermestidae, Bostrichidae, and Anobiidae of the Maritime Provinces of Canada (Coleoptera: Bostrichiformia)
}

\section{CHRISTOPHER G. MAJKA}

Nova Scotia Museum, 1747 Summer Street, Halifax, Nova Scotia, Canada B3H 3A6. E-mail: c.majka@ns.sympatico.ca

\section{Table of contents}

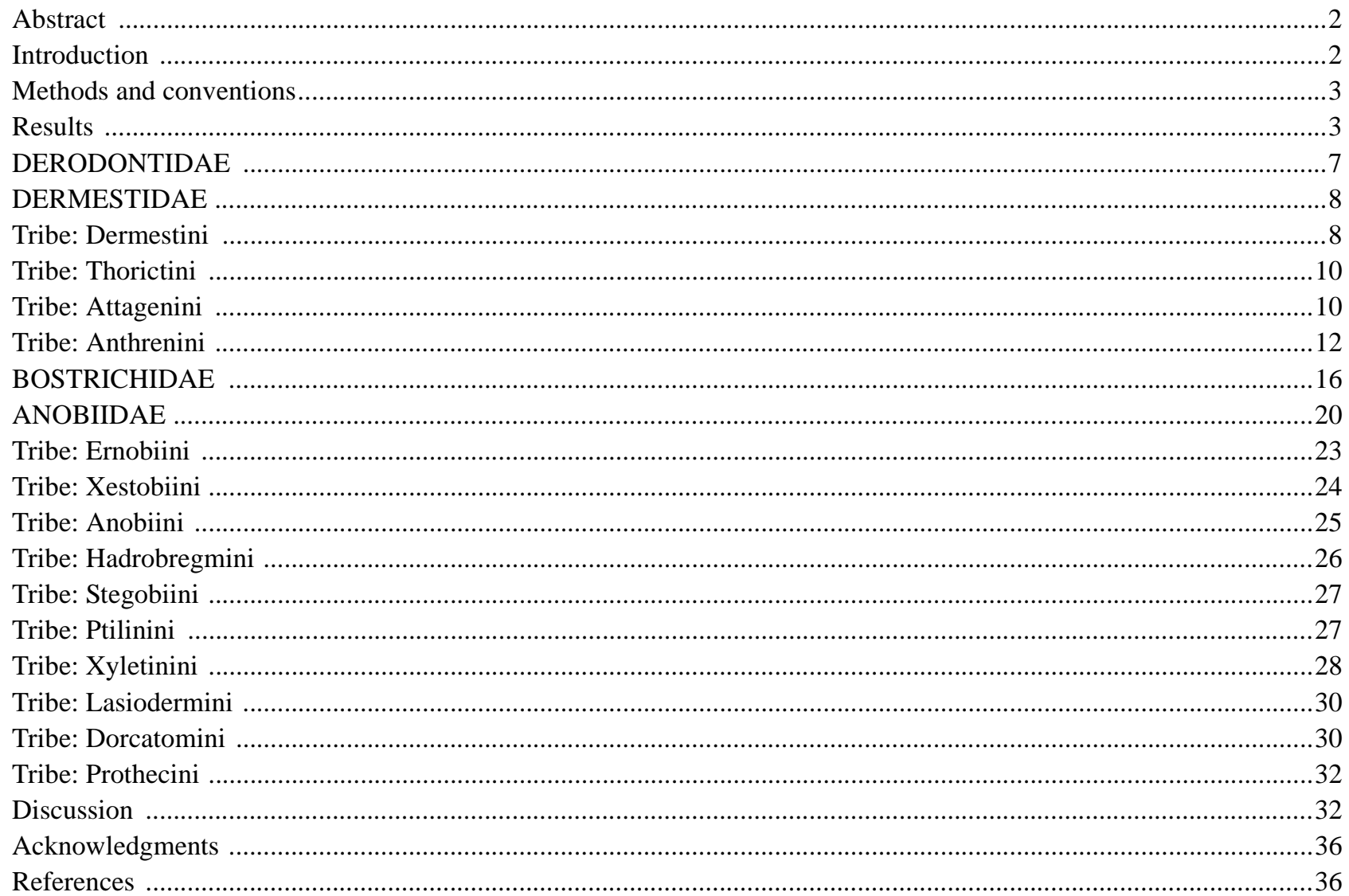




\begin{abstract}
The beetle families of the Bostrichiformia - the Derodontidae, Dermestidae, Bostrichidae, and Anobiidae - in the Maritime Provinces of Canada are surveyed. Seventy-four native and established introduced species are now known to occur including 30 found in New Brunswick, 65 in Nova Scotia, and 29 on Prince Edward Island. Seven species are newly recorded from New Brunswick, 24 from Prince Edward Island, and 37 from Nova Scotia for a total of 68 new provincial records. A total of 31 species are newly recorded in the Maritime Provinces as a whole, three of which, Dinoderus minutus (Fabricius), Ernobius filicornis LeConte, and Ernobius granulatus LeConte, are newly recorded in Canada. Two species, Ptilinus pruinosus Casey and Caenocara oculata (Say), are removed from the faunal list of New Brunswick, and one subspecies, Attagenus unicolor unicolor (Brahm), is removed from the faunal list of Prince Edward Island since no specimens or published records could be found to support their presence.

Additional records of six other exotic species intercepted at ports and points in the region, but not established here, are also reported. A specimen of the Palearctic Ptinus bicinctus Sturm collected in 1915 in Nova Scotia, establishes a new early timeline for this species in North America. The fauna of the region is distinguished by the very large proportion ( 37 of 74 species, i.e. 50\%) of which is introduced. It is also distinguished by the large proportion ( 22 of 37 species, i.e. $60 \%$ ) of the indigenous, native fauna that is apparently rare, perhaps as a result of the historical impact of forest management practices on these wood-boring, saproxylic species. The fauna is further evaluated from both zoogeographic and ecological perspectives.
\end{abstract}

Key words: Coleoptera, Bostrichiformia, Derodontidae, Dermestidae, Bostrichidae, Anobiidae, Maritime Provinces, Canada, biodiversity, introduced species, new records

\title{
Introduction
}

The Derodontidae, Dermestidae, Bostrichidae, and Anobiidae are four of six families in the Bostrichiformia found in North America (no species of Jacobsoniidae or Nosodendriidae, the other two families in the Series, are found in the Maritime Provinces). These beetles are an ecologically diverse grouping in North America which include many wood borers in the Bostrichidae, Ernobiinae, Anobiinae, Ptilininae, and Xyletininae; species that feed on dried, stored product in the Dermestidae and Ptininae; other species associated with carrion in the Dermestidae; fungus feeding species in the Derodontinae and Dorcatominae; and predators of Homoptera in the Laricobiinae.

Because many beetles in this suite of families are in various ways synanthropic, the North American fauna also includes a substantial number of introduced species. Some of these we now know were introduced to the continent long ago. Archeological evidence shows that species such as Dermestes lardarius L., Ptinus fur L., and Tipnus unicolor (Piller \& Mitterpacher) were already established in North America in the early to mid 17th century (Bain 1998, Prévost \& Bain 2006). Continuing international commerce means that there are ongoing introductions and interceptions of many other species. For instance, 34 species of bostrichids have been intercepted at various ports or points in North America, but are apparently not established (Ivie 2002). Many species are of considerable economic importance as stored, dried-product pests; pests of wool, fur, hides, and other animal products; and as borers in dried wood, lumber, furniture, crating, hardwood floors, and other wood products.

Despite their economic importance, relatively little attention has been paid to theses species in the Maritime Provinces of Canada. Bousquet (1991a) recorded only 10 species of dermestids, McNamara (1991a, 1991b) recorded 4 species of bostrichids, McNamara (1991c) and Bousquet (1991b) recorded 22 species of anobiids, and Bright (1991) recorded 4 species of derodontids in the Maritime Provinces for a combined regional fauna of 40 species. Recent research on the biological diversity of Coleoptera in the Maritime Provinces has revealed that the fauna of the region is substantially greater than previously documented. The present paper summarizes these findings and surveys the fauna within the region. 


\section{Methods and conventions}

Codens (following Evenhuis 2007) of collections referred to in this study are:

$\begin{array}{ll}\text { ACNS } & \text { Agriculture and Agri-food Canada, Kentville, Nova Scotia } \\ \text { ACPE } & \text { Agriculture and Agri-food Canada, Charlottetown, Prince Edward Island } \\ \text { CBU } & \text { Cape Breton University, Sydney, Nova Scotia } \\ \text { CGMC } & \text { Christopher G. Majka collection, Halifax, Nova Scotia } \\ \text { CNC } & \text { Canadian National Collection of Insects, Arachnids, and Nematodes, Ottawa, Ontario } \\ \text { DHWC } & \text { David H. Webster collection, Kentville, Nova Scotia } \\ \text { GSC } & \text { Gary Selig collection, Bridgewater, Nova Scotia } \\ \text { JCC } & \text { Joyce Cook collection, North Augusta, Ontario } \\ \text { JOC } & \text { Jeffrey Ogden collection, Truro, Nova Scotia } \\ \text { JRMC } & \text { J. Robert Mutch collection, Charlottetown, Prince Edward Island } \\ \text { NBM } & \text { New Brunswick Museum, Saint John, New Brunswick } \\ \text { NSAC } & \text { Nova Scotia Agricultural College, Bible Hill, Nova Scotia } \\ \text { NSMC } & \text { Nova Scotia Museum, Halifax, Nova Scotia } \\ \text { NSNR } & \text { Nova Scotia Department of Natural Resources, Shubenacadie, Nova Scotia } \\ \text { RPWC } & \text { Reginald P. Webster collection, Charters Settlement, New Brunswick } \\ \text { SMU } & \text { Saint Mary's University, Halifax, Nov Scotia } \\ \text { UMNB } & \text { Université de Moncton, Moncton, New Brunswick } \\ \text { UPEI } & \text { University of Prince Edward Island, Charlottetown, Prince Edward Island }\end{array}$

The number of specimens is indicated in brackets. Where the number of specimens is not specified, it is assumed to be one. Where there are fewer than 20 records, all are reported. Where there are more than 20, a summary of specimens examined is provided and the earliest collections are noted. The systematics follows that of Ivie (2002), Kingsolver (2002), Leschen (2002), and Philips (2002).

\section{Results}

In the course of the present research, 33 specimens of Derodontidae, 715 specimens of Dermestidae, 173 specimens of Bostrichidae, and 1,070 specimens of Anobiidae (total $=1,984$ ) were examined. Of these, 125 originated in New Brunswick, 1,713 in Nova Scotia, and 153 on Prince Edward Island. As a result, the regional fauna is now known to include 74 native and established introduced species, including 30 found in New Brunswick, 64 in Nova Scotia, and 29 on Prince Edward Island. Seven species are newly recorded from New Brunswick, 24 from Prince Edward Island, and 37 from Nova Scotia for a total of 68 new provincial records. A total of 31 species are newly recorded in the Maritime Provinces as a whole, three of which, Dinoderus minutus (Fabricius), Ernobius filicornis LeConte, and Ernobius granulatus LeConte, are newly recorded in Canada (Table 1).

Additionally records of six other exotic species intercepted at ports and points in the region, but not established here, are also reported (Table 1). Two species, Ptilinus pruinosus Casey and Caenocara oculata (Say), are removed from the faunal list of New Brunswick, and the subspecies Attagenus unicolor unicolor (Brahm) is removed from the faunal list of Prince Edward Island, since no specimens or published records could be found to authenticate their presence in the provinces. A specimen of Ptinus bicinctus Sturm collected in 1915 in Nova Scotia establishes a new early timeline for the presence of this species in North America. Specific accounts follow. 
TABLE 1. The Derodontidae, Dermestidae, Bostrichidae, and Anobiidae (Coleoptera: Bostrichiformia) of the Maritime Provinces of Canada.

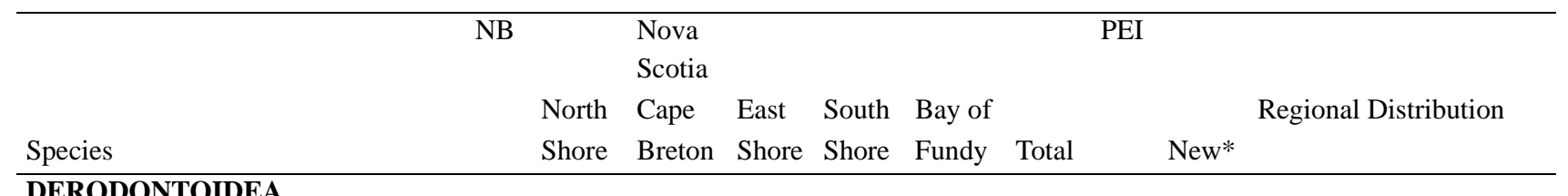

\section{DERODONTOIDEA DERODONTIDAE}

Laricobiinae

Laricobius erichsonii Rosenhauer $\dagger \quad 5 \quad 2$

Laricobius rubidus LeConte

1

1

1

ME, NB, NS, NF

ME, NB, NH, NY, ON, QC, RI

\section{Derodontinae}

Derodontus esotericus Lawrence

Derodontus maculatus Melsheimer

\section{BOSTRICHOIDEA}

\section{DERMESTIDAE}

Dermestini

Dermestes frischii Kugelann $\dagger$

Dermestes lardarius Linnaeus $\dagger$

94

(20)

Dermestes maculatus DeGeer $\dagger$

Dermestes pulcher LeConte

Dermestes talpinus Mannerheim

Dermestes undulatus Brahm $\dagger$

Thorictini

Thylodrias contractus Motschulsky †

Attagenini

Attagenus pellio (Linnaeus) $\dagger$

Attagenus unicolor unicolor (Brahm)

$\dagger$

$\begin{array}{lllllllll}\text { Attagenus unicolor japonicus Reitter } & 4 & 1 & 2 & 1 & 2 & 3 & 9 & 2\end{array}$ $\dagger$

Anthrenini

$\begin{array}{lllllllll}\text { Anthrenus castaneae Melsheimer } & 4 & 4 & 1 & 2 & 3 & 3 & 12 & 2\end{array}$

Anthrenus fuscus Olivier $\dagger$

2

Anthrenus museorum (Linnaeus) $\dagger$

1

Anthrenus scrophulariae (Linnaeus) $\quad 1 \quad 1$

$+$

Anthrenus verbasci (Linnaeus) $\dagger$

$\begin{array}{ll}1 & M \\ 1 & M\end{array}$

1

$\begin{array}{llll}1 & 1 & 2 & 4 \\ 1 & & & 1 \\ 1 & 2 & 3 & 9 \\ 2 & 3 & 3 & 1\end{array}$

$\begin{array}{lllll}2 & 1 & 2 & 6 & 2\end{array}$

$1 \quad 1 \quad \mathrm{M}$

3

M
M

MA, NH, NS, NY, ON, QC, RI

MA, ME, NB, NF, NH, NS, ON, PE, QC, RI

ON, PE, QC, RI

NB, NH, NY, QC

$\mathrm{NB}, \mathrm{NH}, \mathrm{NS}, \mathrm{NY}, \mathrm{ON}$,

QC, RI

M

MA, NH, NS, ON

M

MA, NS, ON, QC, RI

MA, ME, NH, NS, ON, QC, RI

NF, NS, ON, PE, QC

MA, ME, NF, NH, NS, ON, PE, QC

CT, MA, ME, NB, NH, NS, NY, ON, PE, QC, RI, VT

NH, NS, NY, ON, PE, QC, VT

CT, MA, ME, NS, NF, ON, PE, QC, RI

CT, MA, ME, NB, NH, NS, NY, ON, PE, QC, RI MA, ME, NH, NS, ON, QC, RI 


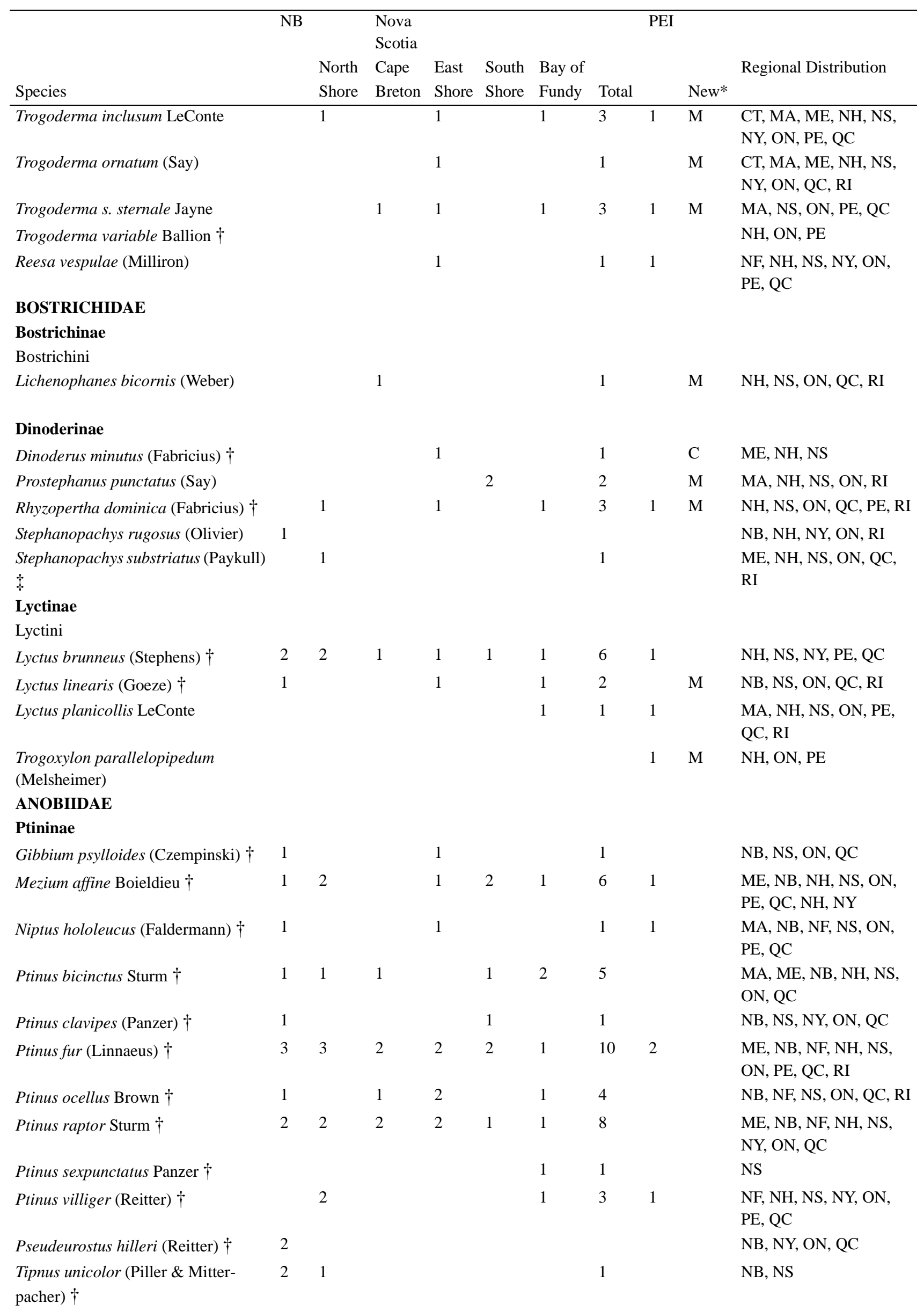




\begin{tabular}{|c|c|c|c|c|c|c|c|c|c|c|}
\hline \multirow[b]{2}{*}{ Species } & \multirow[t]{2}{*}{ NB } & \multicolumn{3}{|c|}{$\begin{array}{l}\text { Nova } \\
\text { Scotia }\end{array}$} & \multirow[b]{2}{*}{$\begin{array}{l}\text { South } \\
\text { Shore }\end{array}$} & \multirow[b]{2}{*}{$\begin{array}{l}\text { Bay of } \\
\text { Fundy }\end{array}$} & \multirow[b]{2}{*}{ Total } & \multicolumn{2}{|c|}{ PEI } & \multirow[b]{2}{*}{ Regional Distribution } \\
\hline & & $\begin{array}{l}\text { North } \\
\text { Shore }\end{array}$ & $\begin{array}{l}\text { Cape } \\
\text { Breton }\end{array}$ & $\begin{array}{l}\text { East } \\
\text { Shore }\end{array}$ & & & & & New* & \\
\hline \multicolumn{11}{|l|}{ Ernobiinae } \\
\hline \multicolumn{11}{|l|}{ Ernobiini } \\
\hline Ernobius filicornis LeConte & & & & & 1 & & 1 & & $\mathrm{C}$ & MA, ME, NH, NS \\
\hline Ernobius granulatus LeConte & & 1 & & & 1 & & 2 & & $\mathrm{C}$ & MA, NS, NY, RI \\
\hline Ernobius mollis (Linnaeus) $\dagger$ & 1 & 1 & & 1 & 1 & 2 & 5 & 1 & & $\begin{array}{l}\text { MA, ME, NF, NH, NS, } \\
\text { NY, ON, PE, QC, RI }\end{array}$ \\
\hline Ernobius schedli Brown & & & & & & 1 & 1 & & M & $\mathrm{NF}, \mathrm{NS}, \mathrm{ON}, \mathrm{QC}$ \\
\hline \multicolumn{11}{|l|}{ Xestobiini } \\
\hline Utobium marmoratum Fisher & & 1 & & & & 1 & 2 & & M & NS \\
\hline Xestobium gaspensis White & & & & 1 & & & 1 & & M & NS, ON, QC \\
\hline \multicolumn{11}{|l|}{ Anobiinae } \\
\hline \multicolumn{11}{|l|}{ Anobiini } \\
\hline Anobium punctatum (DeGeer) $\dagger$ & & 2 & & 2 & 1 & & 6 & & & NF, NS, NY, QC \\
\hline Hemicoelus carinatus (Say) & 1 & 3 & 1 & 2 & 2 & 3 & 11 & 1 & & $\begin{array}{l}\text { MA, ME, NH, NB, NS, } \\
\text { ON, PE, QC, RI, VT }\end{array}$ \\
\hline Hemicoelus defectus (Fall) & & & & & & & & 2 & M & MA, ON, PE, QC \\
\hline Hemicoelus umbrosus (Fall) & 1 & & & & & & & & & NB, NH, NY, ON, QC \\
\hline $\begin{array}{l}\text { Microbregma e. emarginatum } \\
\text { (Duftschmid) } \dagger\end{array}$ & & 2 & & 2 & 2 & 1 & 6 & 1 & M & $\begin{array}{l}\text { MA, ME, NH, NS, ON, } \\
\text { PE, QC }\end{array}$ \\
\hline Platybregmus canadensis Fisher & & 1 & & 1 & & & 2 & & & $\mathrm{NH}, \mathrm{NS}, \mathrm{ON}$ \\
\hline \multicolumn{11}{|l|}{ Hadrobregmini } \\
\hline Hadrobregmus notatus (Say) & & 4 & 1 & 2 & 2 & 2 & 11 & 1 & & $\begin{array}{l}\text { MA, ME, NH, NS, ON, } \\
\text { PE, QC, RI }\end{array}$ \\
\hline Priobium sericeum (Say) & 1 & 1 & & 1 & & & 1 & 1 & & $\begin{array}{l}\text { MA, ME, NB, NH, NS, } \\
\text { NY, ON, PE, QC, VT }\end{array}$ \\
\hline \multicolumn{11}{|l|}{ Stegobiini } \\
\hline Oligomerus sericans (Melsheimer) & & & & 1 & 1 & & 2 & & M & MA, NS, NY, ON, QC \\
\hline Stegobium paniceum (Linnaeus) $\dagger$ & 1 & 3 & 1 & 2 & 1 & 1 & 8 & 1 & & $\begin{array}{l}\text { MA, ME, NB, NF, NH, } \\
\text { NS, ON, PE, QC, RI }\end{array}$ \\
\hline \multicolumn{11}{|l|}{ Ptilininae } \\
\hline \multicolumn{11}{|l|}{ Ptilinini } \\
\hline Ptilinus lobatus Casey & & & & & 1 & & 1 & & M & $\mathrm{NS}, \mathrm{ON}$ \\
\hline Ptilinus pruinosus Casey & & & & & 1 & & 1 & & & $\mathrm{NB}, \mathrm{NS}, \mathrm{ON}, \mathrm{QC}$ \\
\hline Ptilinus ruficornis Say & & 2 & & 2 & 2 & 1 & 7 & & & $\begin{array}{l}\text { MA, ME, NH, NS, ON, } \\
\text { QC, RI, VT }\end{array}$ \\
\hline \multicolumn{11}{|l|}{ Xyletininae } \\
\hline \multicolumn{11}{|l|}{ Xyletinini } \\
\hline Euvrilletta peltata (Harris) & & & & & & & & 1 & M & ON, PE, QC, RI \\
\hline Vrilletta laurentina Fall & & & & & 1 & & 1 & & M & NS, NY, ON, QC \\
\hline $\begin{array}{l}\text { Xyletinus fucatus LeConte } \\
\text { Lasiodermini }\end{array}$ & \multicolumn{9}{|c|}{ Lasiodermini } & $\mathrm{NB}, \mathrm{NF}, \mathrm{ON}, \mathrm{QC}$ \\
\hline Lasioderma serricorne (Fabricius) $\dagger$ & 2 & 2 & & 2 & 1 & 1 & 6 & 1 & M & $\begin{array}{l}\text { MA, ME, NB, NH, NS, } \\
\text { ON, PE, QC, RI }\end{array}$ \\
\hline \multicolumn{11}{|l|}{ Dorcatominae } \\
\hline \multicolumn{11}{|l|}{ Dorcatomini } \\
\hline Byrrhodes intermedius (LeConte) & & & & & 1 & & 1 & & M & MA, NH, NS, NY, QC \\
\hline Caenocara oculata (Say) & & 1 & & 2 & 2 & 1 & 6 & & & $\begin{array}{l}\text { MA, ME, NB, NH, NS, } \\
\text { ON, QC, RI }\end{array}$ \\
\hline
\end{tabular}




\begin{tabular}{|c|c|c|c|c|c|c|c|c|c|c|}
\hline \multirow[b]{2}{*}{ Species } & \multirow[t]{2}{*}{ NB } & \multicolumn{3}{|c|}{$\begin{array}{l}\text { Nova } \\
\text { Scotia }\end{array}$} & \multirow[b]{2}{*}{$\begin{array}{l}\text { South } \\
\text { Shore }\end{array}$} & \multirow[b]{2}{*}{$\begin{array}{l}\text { Bay of } \\
\text { Fundy }\end{array}$} & \multirow[b]{2}{*}{ Total } & \multicolumn{2}{|l|}{ PEI } & \multirow[b]{2}{*}{ Regional Distribution } \\
\hline & & $\begin{array}{l}\text { North } \\
\text { Shore }\end{array}$ & $\begin{array}{l}\text { Cape } \\
\text { Breton }\end{array}$ & $\begin{array}{l}\text { East } \\
\text { Shore }\end{array}$ & & & & & New* & \\
\hline Dorcatoma falli White & & 1 & & 2 & 1 & 1 & 5 & & $\mathrm{M}$ & $\begin{array}{l}\text { MA, ME, NH, NS, NY, } \\
\text { ON }\end{array}$ \\
\hline Dorcatoma pallicornis LeConte & 1 & 1 & & 2 & & 1 & 3 & 1 & & $\begin{array}{l}\text { ME, NB, NF, NH, NS, } \\
\text { NY, ON, PE, QC }\end{array}$ \\
\hline \multicolumn{11}{|l|}{ Prothecini } \\
\hline Sculptotheca puberula (LeConte) & & & & 1 & & 1 & 2 & & M & $\begin{array}{l}\text { MA, NH, NS, NY, ON, } \\
\text { QC, VT }\end{array}$ \\
\hline Stagetus profundus (LeConte) & & & & & 1 & & 1 & & M & NS, ON, QC \\
\hline Totals & 55 & 58 & 24 & 57 & 45 & 53 & 230 & 35 & & \\
\hline \multicolumn{11}{|l|}{ INTERCEPTED SPECIES } \\
\hline \multicolumn{11}{|l|}{ Bostrichidae: Bostrichinae } \\
\hline Bostrychoplites cornutus (Olivier) & & & & & & & & 1 & & \\
\hline $\begin{array}{l}\text { Heterobostrychus aequalis (Water- } \\
\text { house) }\end{array}$ & & & & & & & 1 & & & \\
\hline $\begin{array}{l}\text { Heterobostrychus hamatipennis } \\
\text { (Lesne) }\end{array}$ & 1 & & & & & 1 & 1 & & & \\
\hline Sinoxylon anale Lesne & & & & & & & & 1 & & \\
\hline \multicolumn{11}{|l|}{ Bostrichidae: Dinoderinae } \\
\hline Dinoderus bifoveolata Wollaston & & & & & & & & 1 & & \\
\hline \multicolumn{11}{|l|}{ Bostrichidae: Lyctinae } \\
\hline Lyctoxylon japonum Reitter & & & & 1 & & & 1 & & & \\
\hline
\end{tabular}

Note: Numbers indicate the number of county records.

Districts in Nova Scotia consist of the following counties: Northern Shore: Antigonish, Cumberland, Colchester, Pictou, Antigonish; Cape Breton: Cape Breton, Inverness, Richmond, Victoria; Eastern Shore: Guysborough, Halifax, Sable Island; South Shore: Lunenburg, Queens, Shelburne, Yarmouth; Bay of Fundy: Annapolis, Digby, Hants, Kings.

Sable Island, while nominally a part of Halifax County, is geographically and biologically a distinct unit and therefore is treated separately.

PEI, Prince Edward Island, consisting of 3 counties; NB, New Brunswick, consisting of 15 counties.

* M, indicates species newly recorded in the Maritime Provinces; C, indicates a species newly recorded in Canada.

$\dagger$, introduced Palearctic species; †, Holarctic species.

\section{DERODONTIDAE}

\section{Subfamily: Laricobiinae}

\section{Laricobius rubidus LeConte, 1861}

NEW BRUNSWICK: York Co.: Fredericton, 5.v.1922, on white pine aphids, CNC. Nova Scotia: Halifax Co.: Point Pleasant Park, 20.iv.2002, C.G. Majka, on Picea rubens, CGMC; Point Pleasant Park, 27.iv.2002, C.G. Majka, on Pinus banksiana, CGMC; Point Pleasant Park, 27.iv.2002, C.G. Majka, on Abies balsamaea, CGMC; Point Pleasant Park, 9.v.2002, C.G. Majka, on Abies balsamaea, CGMC; Point Pleasant Park, 14.ix.2002, C.G. Majka, on Pinus strobus, CGMC; south-end Halifax, 21.x.2002, C.G. Majka, on Pinus banksiana, CGMC; Queens Co.: Tobeatic Lake, 15.v.2003, P. Dollin, Picea rubens forest, NSMC.

Newly recorded in Nova Scotia (Fig. 1). Found in northeastern North America (Bright 1991; Downie and Arnett 1996). Known to be predaceous on Adelges piceae (Ratzeburg) (Homoptera: Adelgidae) on various 
Pinaceae and on Pineus strobi (Hartig) (Homoptera: Adelgidae) on Pinus strobus L. (Clark and Brown 1960). In Nova Scotia also found on Picea rubens Sarg. and Pinus banksiana Lamb.

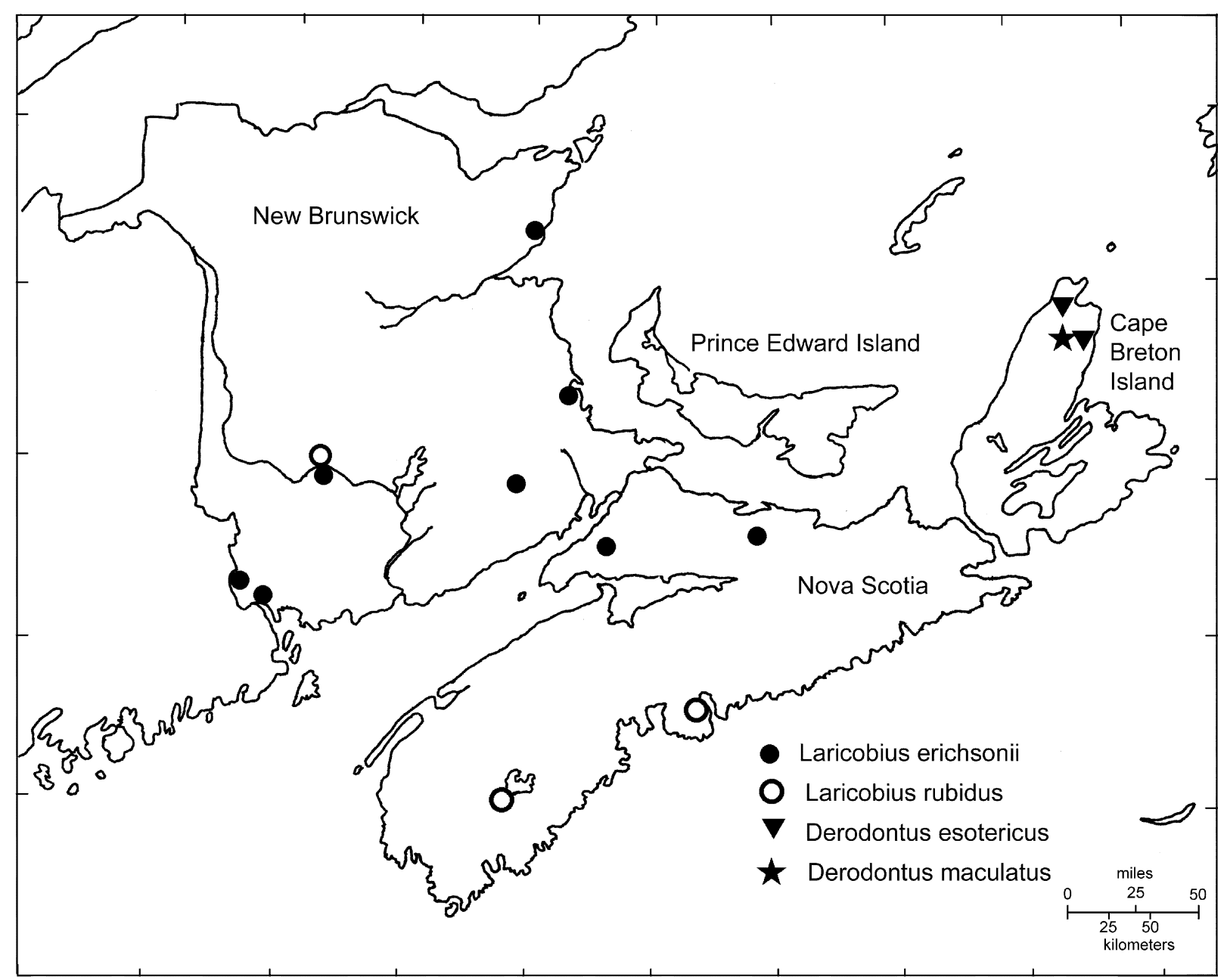

FIGURE 1. Distribution of Laricobius erichsonii Rosenhauer, Laricobius rubidus LeConte, Derodontus esotericus Lawrence, and Derodontus maculatus Melsheimer in the Maritime Provinces of Canada.

\section{DERMESTIDAE}

\section{Tribe: Dermestini}

\section{Dermestes maculatus DeGeer, 1774}

NOVA SCOTIA: Halifax Co.: Halifax, 18.viii.1982, D. McCarthy, intercepted in merchandise from Nigeria, NSMC. PRINCE EDWARD ISLAND: Queens Co.: Charlottetown, x.1975, L.S. Thompson, (2), ACPE.

An introduced Palearctic species newly recorded on Prince Edward Island and the Maritime Provinces as a whole (Fig. 2). Intercepted in Nova Scotia and not established there. Cosmopolitan; found throughout the USA; in Canada recorded from British Columbia east to Québec (Beal 2003). A pest found in houses, on baled skins, and in other products of animal origin (Beal 2003). 


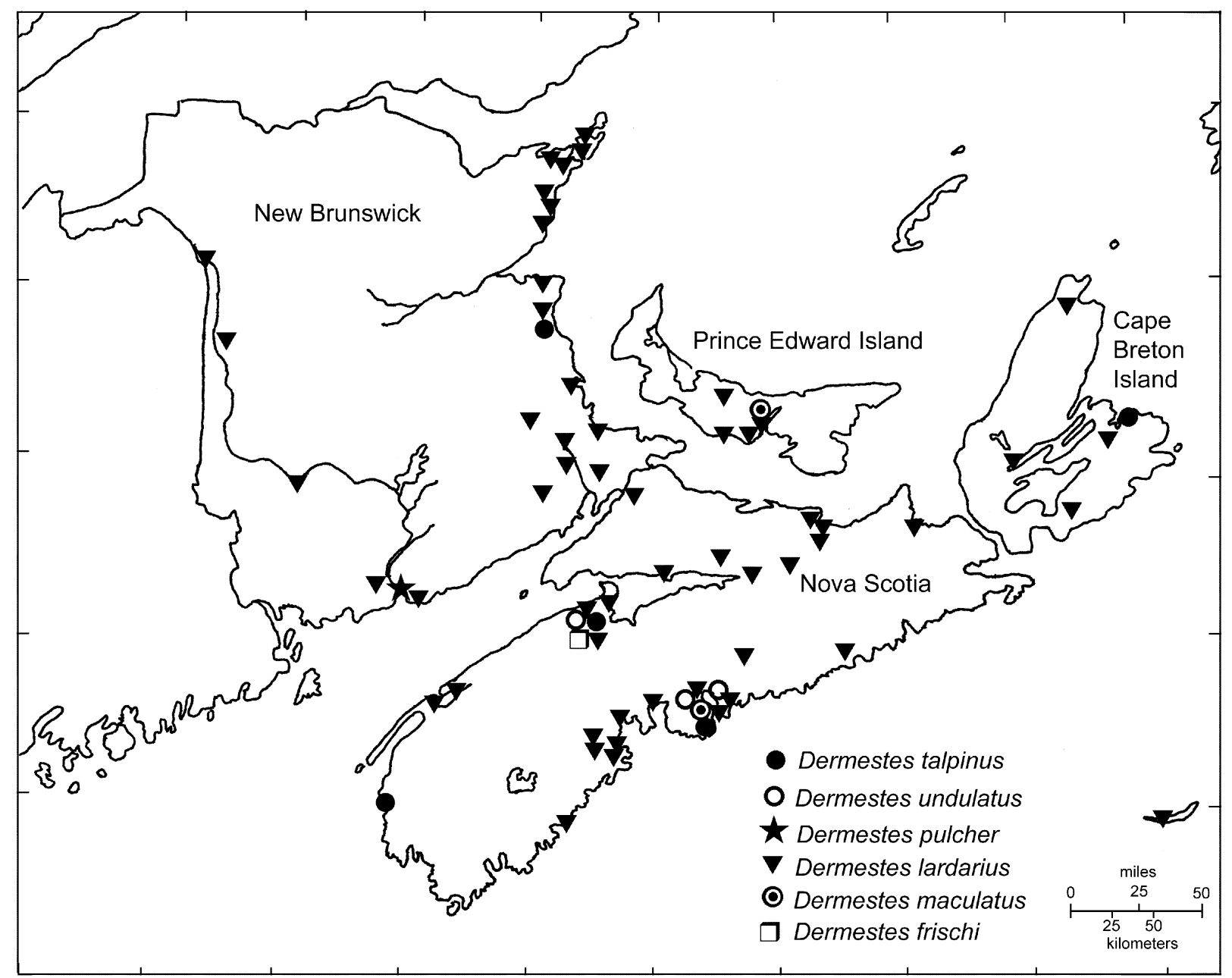

FIGURE 2. Distribution of Dermestes talpinus Mannerheim, Dermestes undulatus Brahm, Dermestes pulcher LeConte, Dermestes lardarius Linnaeus, Dermestes maculatus DeGeer, and Dermestes frischii Kugelann in the Maritime Provinces of Canada.

\section{Dermestes pulcher LeConte, 1854}

NEW BRUNSWICK: Saint John Co.: Saint John, v.190?, W. McIntosh, NBM.

Newly recorded in New Brunswick and the Maritime Provinces as a whole (Fig. 2). Recorded from scattered states in the eastern and central USA (Beal 2003); in Canada known from Manitoba and Québec (Bousquet 1991). Found on carrion (A. Herrmann, pers. comm.)

\section{Dermestes talpinus Mannerheim, 1843}

NEW BRUNSWICK: Kent Co.: Kouchibouquac National Park, 22.vi.1978. D.B. Lyons, (2), CNC. NOVA SCOTIA: Cape Breton Co.: South Bar, 3.viii.1995, A. Brown, CBU; Colchester Co.: Shubenacadie, 19.viii.2004, D. MacDonald, NSNR; Digby Co.: Mavilette Beach, 20.vii.1993, J. \& T. Cook, beach dune, JCC; Halifax Co.: Herring Cove, 5.vi.1947, D.C. Ferguson, NSMC; Kings Co.: Kentville, 11.v.1961, D.H. Webster, on decaying fox, DHWC; Kentville, 18.vii.2003, J. Ogden \& N. Wood, (2), NSNR. 
Newly recorded in Nova Scotia. Found in the western and northern USA north to Alaska; in Canada recorded throughout the country from the Yukon and Northwest Territories and British Columbia east to New Brunswick (Beal 2003, Bousquet 1991). Found on dry carrion (Hatch 1962). In the Maritime Provinces found both on carrion and in beach drift environments.

\section{Dermestes undulatus Brahm, 1790}

NOVA SCOTIA: Halifax Co.: Burnside, 20.v-20.vii.2003, C. Cormier, on decaying pig, (14), SMU; Burnside, 7.vi-25.vi.2004, C. Cormier, on decaying pig, (4), SMU; Point Pleasant Park, 2.vi.2002, C.G. Majka, on dead crow, CGMC; Point Pleasant Park, 23.vi.2002, C.G. Majka, in beach drift, (2), CGMC; Kings Co.: Kentville, 14.v.2006, D.H. Webster, DHWC.

An introduced Palearctic species, newly recorded in Nova Scotia and in the Maritime Provinces as a whole (Fig. 2). In the USA recorded from Colorado, Delaware, Massachusetts, New Hampshire, New Jersey, Ontario, and West Virginia; in Canada recorded from Ontario (Beal 2003). In the Maritime Provinces found both on carrion and in beach drift environments.

\section{Tribe: Thorictini}

\section{Thylodrias contractus Motschulsky, 1839}

NOVA SCOTIA: Kings Co.: Kentville, 10.vii.1978, H.B. Specht, at light in residence, ACNS.

An introduced Palearctic species, newly recorded in Nova Scotia and in the Maritime Provinces as a whole (Fig. 3). Widely distributed in the USA (Beal 2003); in Canada recorded from the Northwest Territories, Alberta, Manitoba, Ontario, and Québec (Bousquet 1991). A synanthropic species associated with dried stored products and a pest in museums and insect collections. (Mertins 1981).

\section{Tribe: Attagenini}

\section{Attagenus pellio (Linnaeus, 1758)}

NEW BRUNSWICK: Albert Co.: Mary's Point, 27.vii.2003, D.S. Christie, CGMC. NOVA SCOTIA: 30 specimens examined from Annapolis, Halifax, Inverness, Kings, and Lunenburg counties (Table 1). The earliest record is from 1930 (Annapolis Co.: Annapolis Royal, 10.v.1930, F.C. Gilliatt, in house, ACNS).

An introduced Palearctic species, newly recorded in New Brunswick (Fig. 3). In the USA recorded from Kentucky, Massachusetts, Maine, New Hampshire, and Rhode Island (Beal 2003, Chandler 2001, Sikes 2004); in Canada recorded British Columbia, Ontario, Québec, and Nova Scotia (Bousquet 1990). A household pest found on wool, furs, skins, and other materials of animal origin; also found in warehouses and museum collections feeding on insect remains (Bousquet 1990).

\section{Attagenus unicolor unicolor (Brahm, 1791)}

NOVA SCOTIA: Halifax Co.: Halifax, 25.vi.1992, collector not recorded, (4), NSMC.

An introduced Palearctic beetle, newly recorded in Nova Scotia and in the Maritime Provinces as a whole 
(Fig. 3). Beal (2003) indicated that A. u. unicolor had been found on Prince Edward Island, however, in the present study only A. u. japonicus specimens were found there and neither voucher specimens nor published records of the former from the province could be located. R. Beal (pers. com.) could not find a source for the original report and now considers it to have been in error. Accordingly, A. u. unicolor is removed from the faunal list of Prince Edward Island. Found throughout the USA; in Canada recorded from British Columbia east to Québec and in Newfoundland (Beal 2003). For bionomics see A. u. japonicus (below).

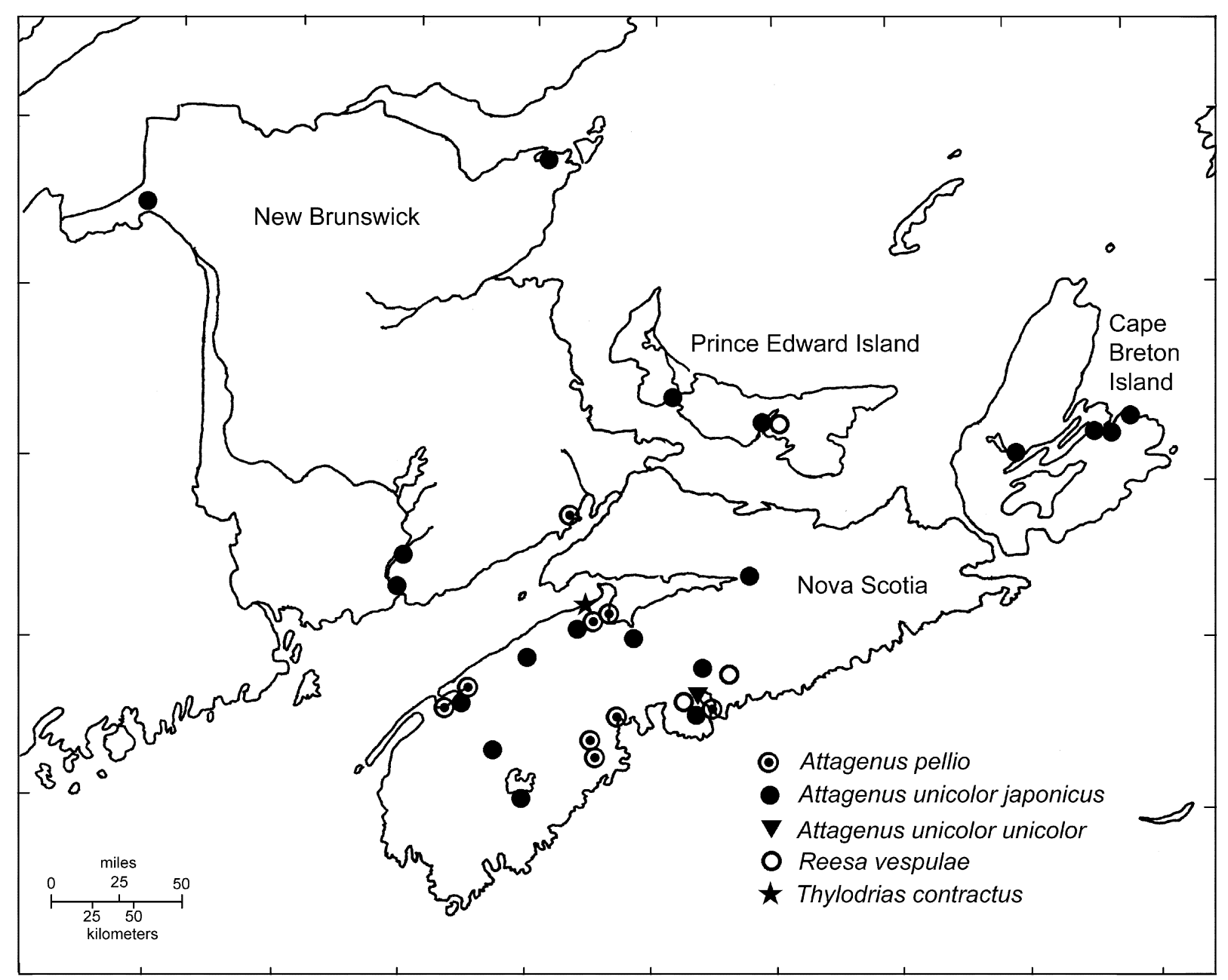

FIGURE 3. Distribution of Attagenus pellio (Linnaeus), Attagenus unicolor japonicus Reitter, Attagenus u. unicolor (Brahm), Reesa vespulae (Milliron), and Thylodrias contractus Motschulsky in the Maritime Provinces of Canada.

\section{Attagenus unicolor japonicus Reitter, 1877}

NEW BRUNSWICK: Gloucester Co.: Caraquet, 23.vii.2001, G. Gallant, UMNB; Kings Co.: Long Reach, 19.vii.1971, Mrs. Tilley, UMNB; Madawaska Co.: Edmundston, 8.v.1977, E. Ouellette, UMNB; Saint John Co.: Saint John, 7.vi.1901, W. McIntosh, NBM. NOVA SCOTIA: 91 specimens examined from Colchester, Inverness, Cape Breton, Halifax, Queens, Shelburne, Annapolis, Kings, and Hants counties (Table 1). The earliest record is from 1950 (Colchester Co.: Truro, 25.i.1950, M.E. Neary, NSAC). PRINCE EDWARD ISLAND: Prince Co.: Summerside, 9.vii.1985, L.S. Thompson, ACPE; Queens Co.: Charlottetown, 1985, L.S. Thompson, ACPE; Charlottetown, 8.vii.1960, F.M. Cannon, ACPE, locality not recorded, 1993, collector not recorded, (2), ACPE. 
An introduced Palearctic beetle, newly recorded in New Brunswick and Nova Scotia (Fig. 3). In the USA found from Nevada and Idaho east to Michigan (Beal 2003); in Canada recorded from British Columbia east to Newfoundland (Bousquet 1991). The specimen collected in 1901 in New Brunswick is noteworthy, since it appears to be the earliest museum specimen of this species collected in North America. Bain (1999), however. has found it in latrine deposits in Québec that date from 1860 indicating an earlier introduction. Larvae feed on wool, fur, skins, feathers, and other materials of animal origin; also found in grain elevators, flour and feed mills, and attacking museum specimens, and insect collections. Adults feed on nectar and pollen. In natural conditions found in bird, mammal, and wasp nests (Bousquet 1990).

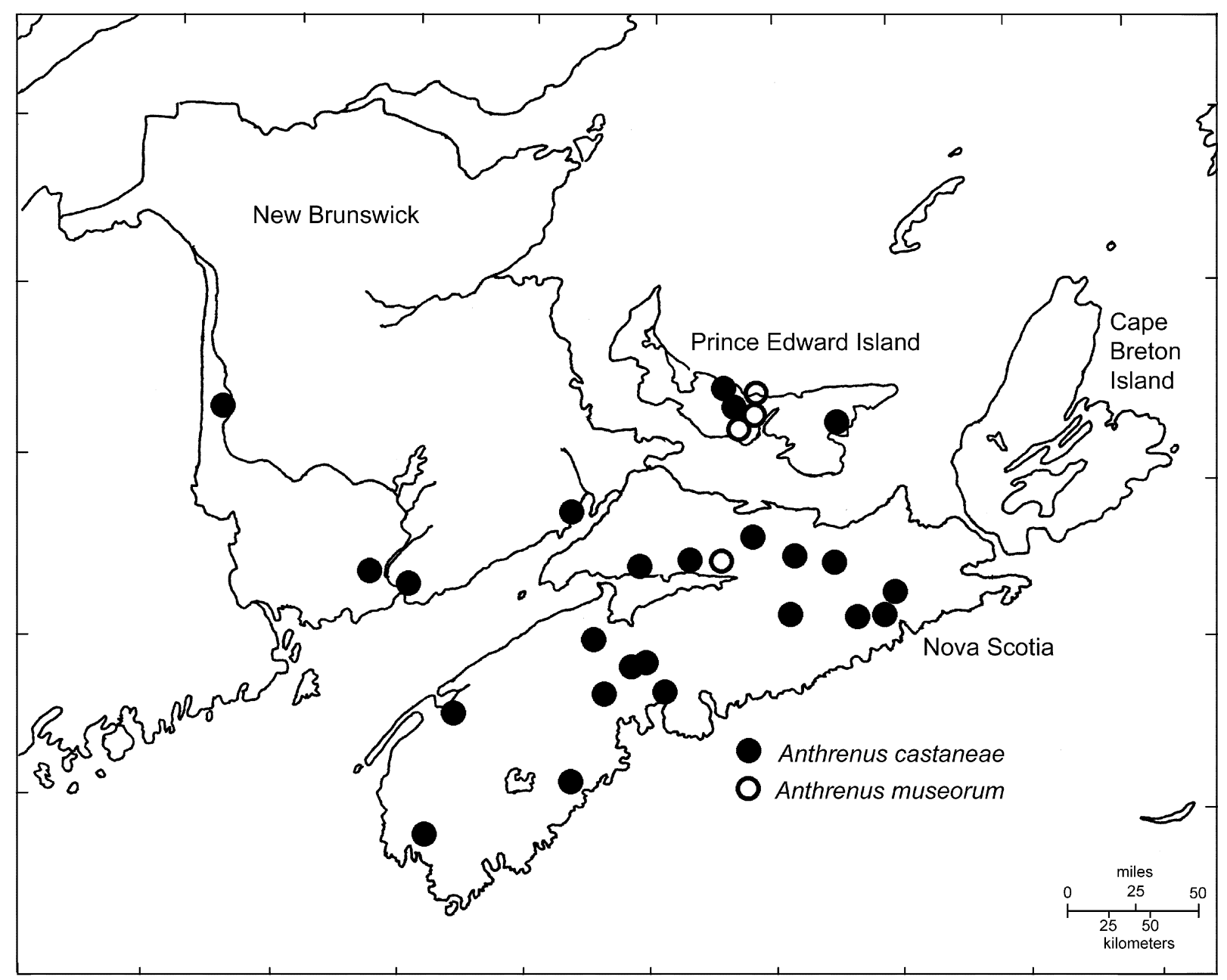

FIGURE 4. Distribution of Anthrenus castaneae Melsheimer and Anthrenus museorum (Linnaeus) in the Maritime Provinces of Canada.

\section{Tribe: Anthrenini}

\section{Anthrenus castaneae Melshimer, 1846}

NEW BRUNSWICK: Albert Co.: Mary's Pt., 12.viii.2004, C.G. Majka, seashore, CGMC; Carleton Co.: Wakefield: Bell Forest Preserve, 1.viii.2004, V. and R. Webster, mixed forest, RPWC; Saint John Co.: Saint John, 10.vii.1901, vi.190?, and viii.190?, W. McIntosh, (4), NBM. NOVA SCOTIA: 67 specimens examined from Cape Breton, Cumberland, Colchester, Pictou, Antigonish, Guysborough, Halifax, Lunenburg, Queens, 
Yarmouth, Annapolis, Kings, and Hants counties. The earliest records are from 1993 (Queens Co.: Medway River, 13.vii.1993, J. \& T. Cook, car-netting, JCC; Yarmouth Co.: Moses lake, 17-22.vii.1993, J. \& T. Cook, mixed forest, flight-intercept trap, (7), JCC). PRINCE EDWARD ISLAND: Kings Co.: Woodville Mills, 23.vii.2001, C.G. Majka, old field, (2), CGMC; Queens Co.: Cavendish, 19.vii.2001, C.G. Majka, seashore, CGMC; Hunter River, 12.vii.2002, C.G. Majka, beside mill pond, CGMC; St. Patricks, 18.viii.2002, old field, CGMC.

Newly recorded in Nova Scotia and Prince Edward Island (Fig. 4). Widely distributed in the USA (Beal 2003); in Canada recorded from Ontario, Québec, and New Brunswick (Bousquet 1991). Common on flowers (Downie \& Arnett 1996).

\section{Anthrenus fuscus Olivier, 1789}

NOVA SCOTIA: 27 specimens examined from Colchester, Pictou, Guysborough, Halifax, Yarmouth, Kings, and Hants counties (Table 1). The earliest records are from 1961 (Kings Co.: Kentville, 20.iv.1961, D.H. Webster, DHWC; Kentville, 29.viii.1961, H.T. Stultz, (2), ACNS). PRINCE EDWARD ISLAND: Prince Co.: Alberton, summer 1993, M.E.M. Smith, ACPE: Queens Co.: Charlottetown, summer 1993, M.E.M. Smith, ACPE.

An introduced Palearctic species, newly recorded on Prince Edward Island (Fig. 5). Scattered records from various states in the USA (Beal 2003); in Canada recorded from Ontario, Québec, and Nova Scotia (Bousquet 1991). A minor pest flour mills, warehouses, and dwellings (Bousquet 1990). In natural conditions found bird and wasp nests, under the bark of trees, and around spider webs (Woodroffe and Southgate 1954).

\section{Anthrenus museorum (Linnaeus, 1761)}

NOVA SCOTIA: Colchester Co.: Debert, 13.v.1996, J. Ogden, JOC. PRINCE EDWARD ISLAND: Queens Co.: Brackley, 9.vii.1983, M.E.M. Smith, ACPE; Charlottetown, 16.ii.1996 and 11.iv.1997, M.E.M. Smith, (2), ACPE; Cornwall, summer 1998, M.E.M. Smith, (3), ACPE.

An introduced Palearctic species, newly recorded in Nova Scotia, Prince Edward Island, and the Maritime Provinces as a whole (Fig. 4). In the USA recorded from Connecticut, Massachusetts, and Wisconsin (Beal 2003); in Canada known from Ontario, Québec, and Newfoundland (Bousquet 1991). A household pest; larvae are found on wool, fur, skins, and other animal products; also on museum specimens and insect collections. Like other species in the genus, adults feed on nectar and pollen, mate in the field, and fly indoors to oviposit (Bousquet 1990).

\section{Anthrenus scrophulariae (Linnaeus, 1758)}

NEW BRUNSWICK: Northumberland Co.: Chatham, 6.vii.1928, W.J. Brown, (17), CNC. NOVA SCOTIA: 33 specimens examined from Colchester, Victoria, Halifax, Lunenburg, Kings, and Hants counties (Table 1). The earliest specimen is from 1948 (Colchester Co.: Truro, 11.iv.1948, no collector recorded, NSAC). PRINCE EDWARD ISLAND: Kings Co.: Woodville Mills, 30.vi.2003, C.G. Majka, shore of pond, CGMC; Prince Co.: Dunk River, 24.vi.1971, A. Joshi, UPEI; Queens Co.: Bonshaw, 9.vi.1982, V. Bryanton, UPEI; Cherry Valley, 25.vi.1971, R. MacLeod, building, UPEI; Cornwall, 1.v.1989 and 19.vi.1983, M.E.M. Smith, in house, (2), ACPE; Meadow Bank, 15.vi.1971, L. Drake, light trap, UPEI.

An introduced Palearctic species, newly recorded on Prince Edward Island (Fig. 5). Widely distributed in 
the northern and central portions of the USA (Beal 2003); in Canada recorded from British Columbia, Ontario, Québec, New Brunswick, and Nova Scotia (Bousquet 1991). Bionomics as in A. museorum (Bousquet 1990).

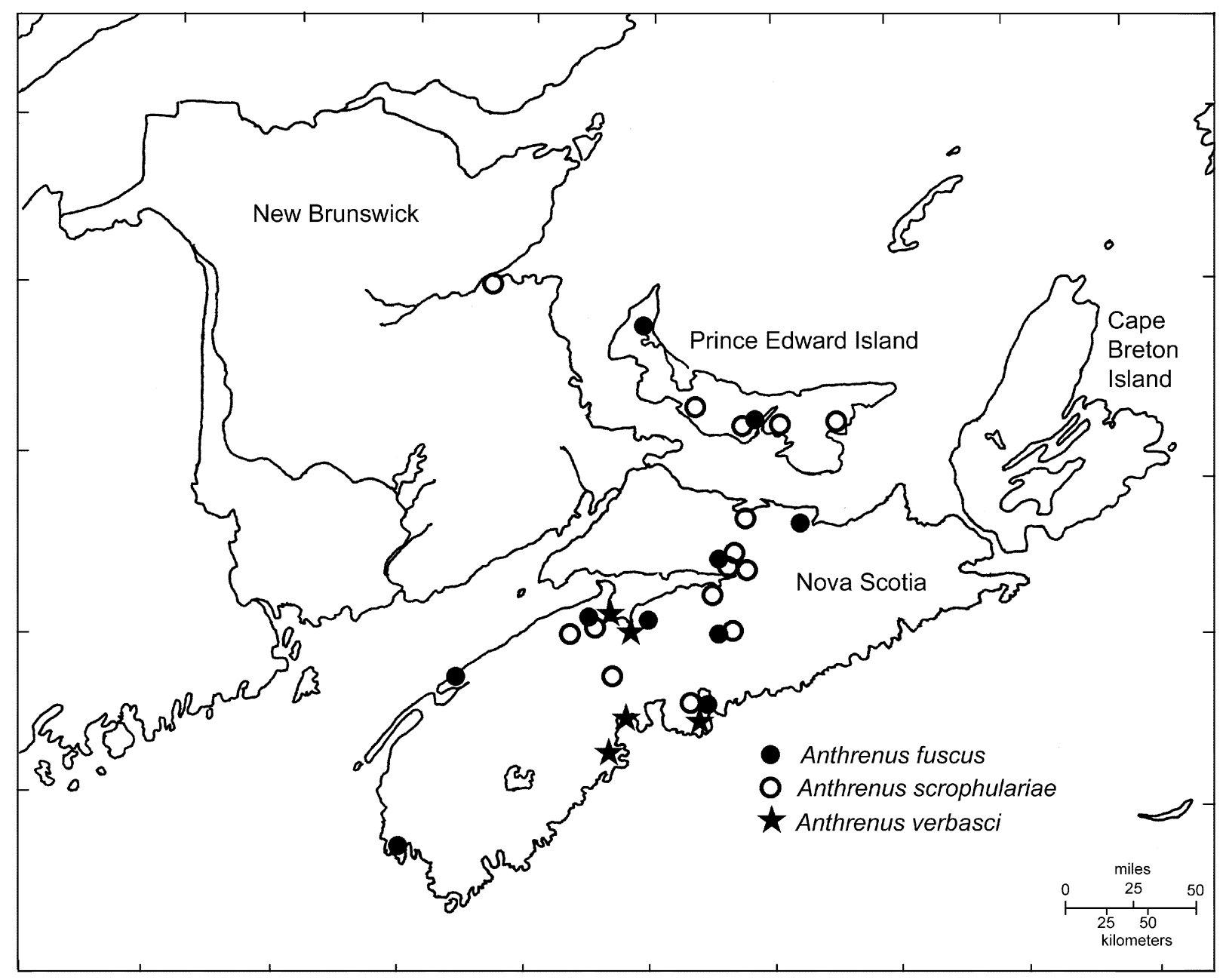

FIGURE 5. Distribution of Anthrenus fuscus Olivier, Anthrenus scrophulariae (Linnaeus) and Anthrenus verbasci (Linnaeus) in the Maritime Provinces of Canada.

\section{Anthrenus verbasci (Linnaeus, 1767)}

NOVA SCOTIA: 86 specimens examined from Halifax, Lunenburg, Kings, and Hants counties (Table 1). The earliest record is from 1948 (Kings Co.: Porter Point, 1.vii.1948, K.D. Archibald, NSMC).

An introduced Palearctic species, newly recorded from Nova Scotia and the Maritime Provinces as a whole (Fig. 5). Cosmopolitan; found throughout the USA (Beal 2003); in Canada recorded from British Columbia, Alberta, Manitoba, Ontario, and Québec (Bousquet 1991). Occasionally found in flour mills and warehouses, however, primarily a household pest; larvae feed on wool, fur, skins, and other materials of animal origin. They also attack insect collections and silkworm cocoons (Bousquet 1990). In natural circumstances adults feed on the nectar and pollen of species of Heracleum, Anthriscus, Aegopodium, Daucus (Apiaceae), Achillea, Anthemis, and Matricaria (Asteraceae) where they subsequently mate. Eggs are laid and larvae feed in nests of sparrows, swallows, corvids, starlings, swifts, and pigeons (Woodroffe \& Southgate 1954). 


\section{Trogoderma inclusum LeConte, 1854}

NOVA SCOTIA: 25 specimens examined from Colchester, Halifax, and Kings counties (Table 1). The earliest record is from 1966 (Kings Co.: Kentville, 13.iv.1966, H.T. Stultz, (2), ACNS. PRINCE EDWARD ISLAND: Queens Co.: Charlottetown, 13.vii.1976, 10.vi.1983, and xi.1978, L.S. Thompson, (3), ACPE.

Newly recorded in Nova Scotia and Prince Edward Island and the Maritime Provinces as a whole (Fig. 6). Widely distributed throughout the USA (Beal 2003); in Canada recorded from British Columbia, Saskatchewan, Manitoba, Ontario, and Québec (Bousquet 1991). A synanthropic species found in a wide variety of animal and vegetable products; regularly encountered in dried-milk factories (Bousquet 1990).

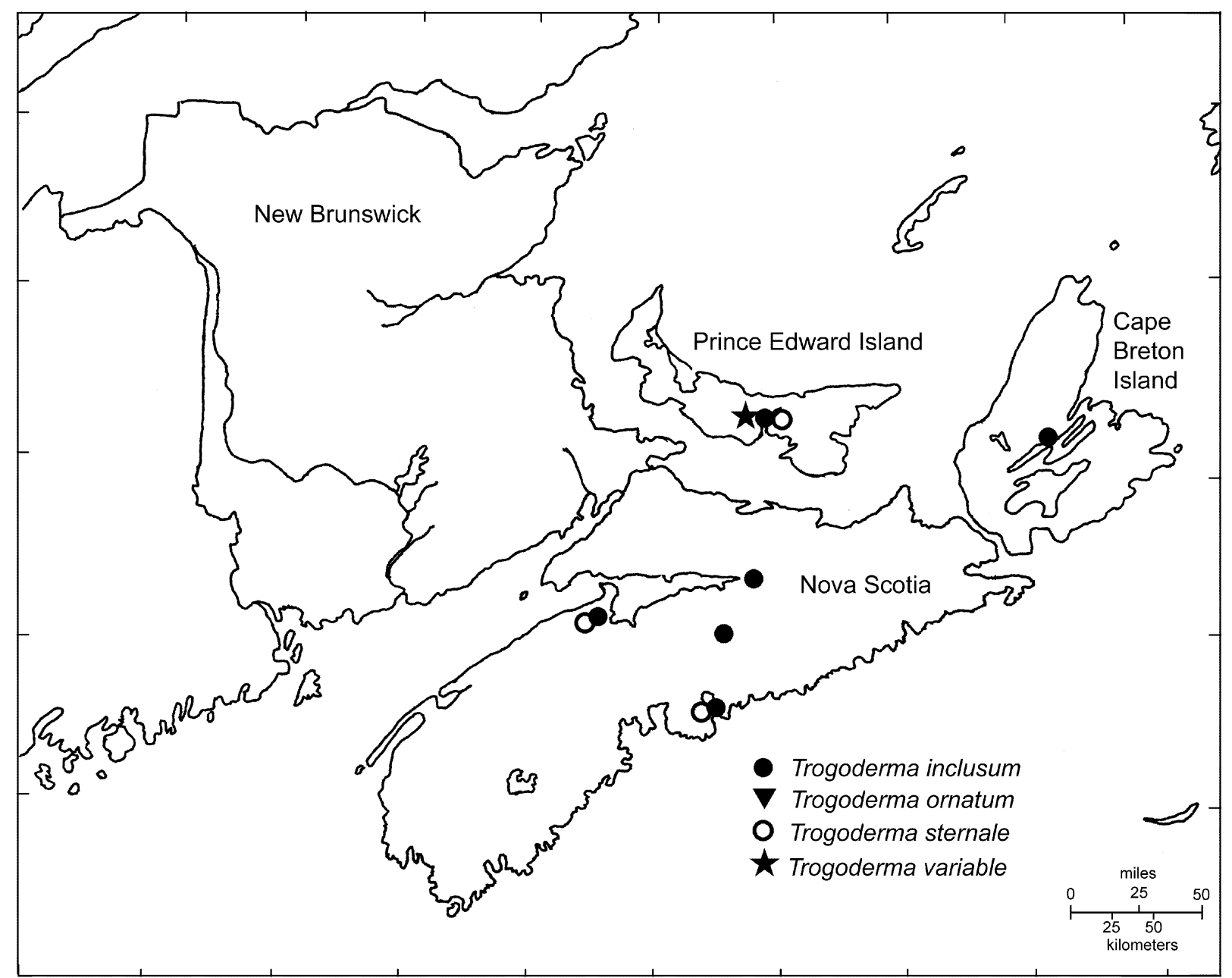

FIGURE 6. Distribution of Trogoderma inclusum LeConte, Trogoderma ornatum (Say), Trogoderma s. sternale Jayne, and Trogoderma variable Ballion in the Maritime Provinces of Canada.

\section{Trogoderma ornatum (Say, 1825)}

NOVA SCOTIA: Halifax Co.: Halifax, 19.x.1990, 4.iii.1991, 3.iv.1991, and summer 1990, B. Wright, (10), NSMC; Porter's Lake, 5.vi.1987, L. Conrad, (3), NSMC.

Newly recorded in Nova Scotia and the Maritime Provinces as a whole (Fig. 6). Widely distributed throughout the USA (Beal 2003); in Canada recorded from Ontario and Québec (Bousquet 1991, Beal 2003). Reported as predators of larvae in nests of Apis mellifera L (Noya \& Velez 1998), Trypoxylon clavatum Say, $T$. 
striatum Provancher, Monobia quadridens (L.), Anthophora bomboides Kirby, and other Hymenoptera (R. Beal, pers. comm.).

\section{Trogoderma sternale sternale Jayne, 1882}

NOVA SCOTIA: Halifax Co.: Halifax, 3.iv.1991 and 5.iv.1991, B. Wright, (4), NSMC; Kings Co.: Kentville, 29.viii.1961, H.T. Stultz, in house, ACNS; Kentville, 30.vi.1961, D.H. Webster, in house, DHWC. PRINCE EDWARD ISLAND: Queens Co.: Charlottetown, 7.viii.1998, M.E.M. Smith, in basement, (3), ACPE.

Newly recorded in Nova Scotia and Prince Edward Island and the Maritime Provinces as a whole (Fig. 6). Widely distributed throughout the USA except for northern New England (Beal 2003); in Canada recorded from British Columbia, Ontario, and Québec (Bousquet 1991). A synanthropic species recorded as a minor pest in animal and vegetable materials; also in granaries and as a pest of insect collections (Bousquet 1990).

\section{Reesa vespulae (Milliron, 1939)}

NOVA SCOTIA: Halifax Co.: Halifax, 7.v.1981, 13.v.1981, 21.v.1981, 15.vi.1981, 1.v.1983, and 24.v.1983, B. Wright, (25), NSMC; Halifax, 14.i.1991, R. Grantham, (2), NSMC; Lake Egmont, 20.vi.1990, E. Parker, NSMC. PRINCE EDWARD ISLAND: Queens Co.: Charlottetown, 4.vii.1986, 1.viii.2000, and summer 1998, M.E.M. Smith, (7), ACPE; Charlottetown, 1.vii.1986, L.S. Thompson, ACPE.

Newly recorded in Nova Scotia (Fig. 3). Found in the northern states in the USA (Beal 2003); in Canada recorded across the country from British Columbia and the Northwest Territories east to Newfoundland. A minor pest of insect and plant collections, occasionally found in granaries and dwellings (Bousquet 1990). In natural circumstances it is a scavenger of dead insects and spiders in wasp nests (Beal 1967).

\section{BOSTRICHIDAE}

\section{Subfamily: Bostrichinae}

\section{Bostrychoplites cornutus (Olivier, 1790)}

PRINCE EDWARD ISLAND: Queens Co.; Montague, 26.x.1988, M.E.M. Smith, emerged from picture frame imported from Africa, ACPE.

An intercepted, adventive species; not established in the region. Newly recorded on Prince Edward Island. Frequently found in wood carvings and other items imported from Africa (Ivie 2002).

\section{Heterobostrychus aequalis (Waterhouse, 1884)}

NOVA SCOTIA: location and date not specified, T. Duke, in wooden items imported from South Africa, NSNR; location and date not specified, found in clothes pins imported from China, (2), NSNR.

An intercepted, adventive species; not established in the region. Newly recorded in Nova Scotia. Established in Florida (Ivie 2002). 
NEW BRUNSWICK: Albert Co.: Riverview, 23.viii.2005, R. Childs, emerged from wicker basket imported from China, CGMC. NOVA SCOTIA: Hants Co.: Windsor, 18.viii.2006, M. Oulton, imported product, NSNR.

An intercepted, adventive species; not established in the region. Newly recorded in New Brunswick and Nova Scotia. Possibly established in Florida (Ivie 2002).

\section{Lichenophanes bicornis (Weber, 1801)}

NOVA SCOTIA: Cape Breton Co.: Catalone, v.1994, H. MacLeod, CBU.

Newly recorded in Nova Scotia and in the Maritime Provinces as a whole (Fig. 7). Found in the United States from New Hampshire south to Texas and Oklahoma and west to Kansas and Nebraska (Downie and Arnett 1996); in Canada recorded from Ontario and Québec (McNamara 1991a). Found under loose bark of many hardwoods (Downie and Arnett 1996).

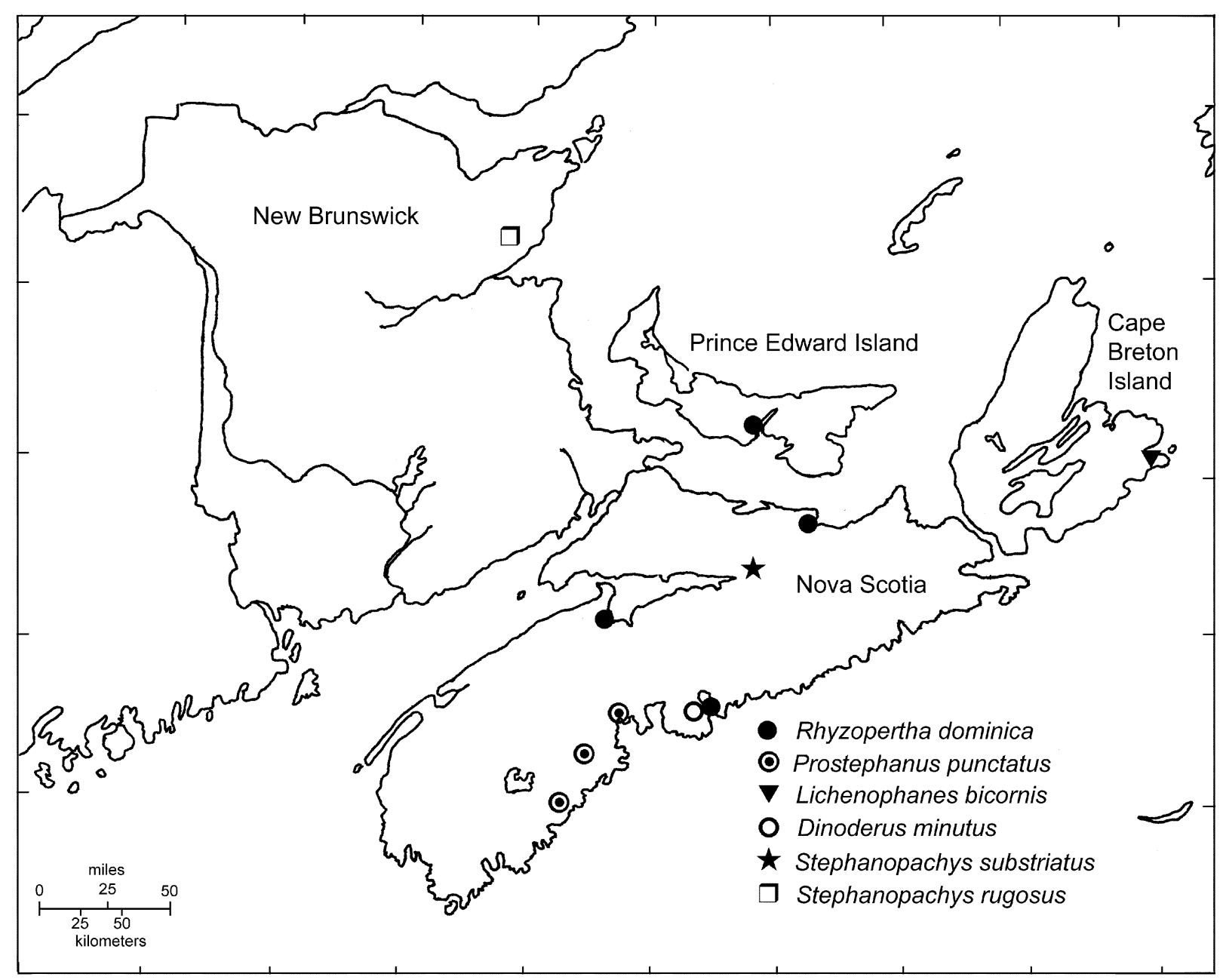

FIGURE 7. Distribution of Rhyzopertha dominica (Fabricius), Prostephanus punctatus (Say), Lichenophanes bicornis (Weber), Dinoderus minutus (Fabricius), Stephanopachys substriatus (Paykull), Stephanopachys rugosus (Olivier) and in the Maritime Provinces of Canada. 
PRINCE EDWARD ISLAND: Queens Co.: Charlottetown, xii.1968, L.S. Thompson, emerged from leg of table, ACPE.

An intercepted, adventive species; not established in the region. Newly recorded on Prince Edward Island. Found from the Middle East across southern Asia to Java and southern China (Joly et al. 1994). It is considered one of the most destructive wood-borers in India, attacking great variety of plants (Fisher 1950).

\section{Subfamily: Dinoderinae}

\section{Dinoderus bifoveolata Wollaston, 1858}

PRINCE EDWARD ISLAND: Queens Co.: Fort Augustus, 14.vi.1989, M.E.M. Smith, emerged from wicker furniture, (4), ACPE.

An intercepted, adventive species; not established in the region. Newly recorded on Prince Edward Island. Found in many tropical regions of the world where it damages many plants and attacks dried stored food. Not established in North America except for a possible transient population in Texas (Spillman 1982).

\section{Dinoderus minutus (Fabricius, 1775)}

NOVA SCOTIA: Halifax Co.: Halifax, 2.xi.1988, B. Wright, in apartment, (15), NSMC.

An adventive species; possibly established in the region. Newly recorded in Nova Scotia and in the Maritime Provinces as a whole (Fig. 7). Cosmopolitan; possibly established in five states in the USA (Spillman 1982). In Canada reported from Ontario to British Columbia where it has been found in warehouses and places where bamboo products are stored (Bousquet 1990). Naturally breeds in dead bamboo in the tropics but also found in dried stored food in North America (Spillman 1982).

\section{Prostephanus punctatus (Say, 1827)}

NOVA SCOTIA: Lunenburg Co.: Chester, 9.vi.1993, J. Ogden, NSNR; Wiles Lake, 6.vi.1989, M. Leblanc, light trap, NSNR; Queens Co.: Milton, 22.vi.1993, E. Georgeson, light trap, NSNR.

Newly recorded in Nova Scotia and in the Maritime Provinces as a whole (Fig. 7). In the United States known from the New England area (Chandler 2001, Sikes 2004); in Canada recorded in Ontario (McNamara 1991a). Breeds in hardwoods such as Quercus (Fagaceae). Commonly attracted to ultraviolet lights (Downie and Arnett 1996).

Rhyzopertha dominica (Fabricius, 1792)

NOVA SCOTIA: Halifax Co.: Halifax, 22.xi.1976, B. Wright, (3), NSMC; Halifax, 9.iii.1982, B. Wright, (10), NSMC; Halifax, 1.vii.1975, Mrs. Provencher, (4), NSAC, Kings Co.: Wolfville, 28.i.1978, D. Krepinsky, ACNS; Pictou Co.: Lyons Brook, 23.iv.1996, E. Georgeson, (22), in stored grains, NSNR. PRINCE EDWARD ISLAND: Queens Co.: Charlottetown, 24.i.1995, M.E.M. Smith, in health-food store, ACPE. 
An established, adventive species. Newly recorded in Nova Scotia, Prince Edward Island, and in the Maritime Provinces as a whole (Fig. 7). Cosmopolitan; in temperate regions confined to buildings; in Canada recorded from British Columbia east to Québec (Bousquet 1990). Primarily found boring in stored wheat and corn, but it can also infest tobacco, nuts, beans, bird seed, biscuits, cassava, cocoa beans, dried fruit, peanuts, spices, and dried meat and fish (Koehler 1999).

\section{Subfamily: Lyctinae}

\section{Lyctoxylon japonum Reitter, 1878}

NOVA SCOTIA: Halifax Co.: Halifax, 21.vii.1992, K. Casselman, emerged from African wooden products, (4), NSMC.

An intercepted, adventive species; not established in the region. Newly recorded in Nova Scotia. An Asian species repeatedly intercepted at various places in North America. Frequently found in bamboo and other wooden products (Gerberg 1957).

\section{Lyctus brunneus (Stephens, 1830)}

NEW BRUNSWICK: Gloucester Co.: Bathurst, 27.xii.1984, CNC; Westmoreland Co.: 25.ix.1984, CNC. NOVA SCOTIA: 63 specimens examined from Colchester, Pictou, Cape Breton, Halifax, Lunenburg, and Kings counties (Table 1). The earliest record is from 1976 (Halifax Co.: Halifax, 1.iv.1976, T. Fowler, NSMC). PRINCE EDWARD ISLAND: Queens Co.: Charlottetown, 7.vii.1983, L.S. Thompson, (2), ACPE.

An established, adventive species. Newly recorded in Prince Edward Island. Cosmopolitan; scattered records in many parts of the USA (Downie and Arnett 1996); in Canada recorded from British Columbia, Québec, New Brunswick, and Nova Scotia (McNamara 1991b). Larvae and adults live in recently dried wood, lumber, furniture, crating, hardwood floors, and other wood products (McNamara 1991b).

\section{Lyctus linearis (Goeze, 1877)}

NEW BRUNSWICK: Saint John Co.: Saint John, vii.190?, W. McIntosh, NBM. NOVA SCOTIA: Annapolis Co.: Annapolis Royal, 15.vi.1932, F.C. Gilliatt, ACNS; Lequille, 15.vi.1932, F.C. Gilliatt, ACNS.

An adventive species, possibly established in the region. Newly recorded in New Brunswick, Nova Scotia and in the Maritime Provinces as a whole (Fig. 8). Cosmopolitan; in Canada recorded from Ontario and Québec (McNamara 1991b). Found in dry wood of ash, wild cherry, hickory, oak, orange, locust, poplar, sycamore, and walnut (Essig 1926).

\section{Lyctus planicollis LeConte, 1858}

NOVA SCOTIA: Halifax Co.: Halifax, 29.vi.1988, Kostopoulos, (10), NSMC; Lower Sackville, 22.ii.1991, R. Marcotte, (3), NSMC. PRINCE EDWARD ISLAND: Queens Co.: Charlottetown, 4.ii.1994, J.G. Stewart, in house, (2), ACPE; Mount Stewart, 27.i.1992, J.G. Stewart, (3), ACPE. 
An adventive species, possibly established in the region. Newly recorded on Prince Edward Island (Fig. 8). A Nearctic species found in many parts of the United States and introduced to Europe (Gerberg 1957). In Canada recorded from British Columbia east to Nova Scotia (McNamara 1991b). Bionomics as in L. brunneus. Wright (1960) successfully reared the species from oak.

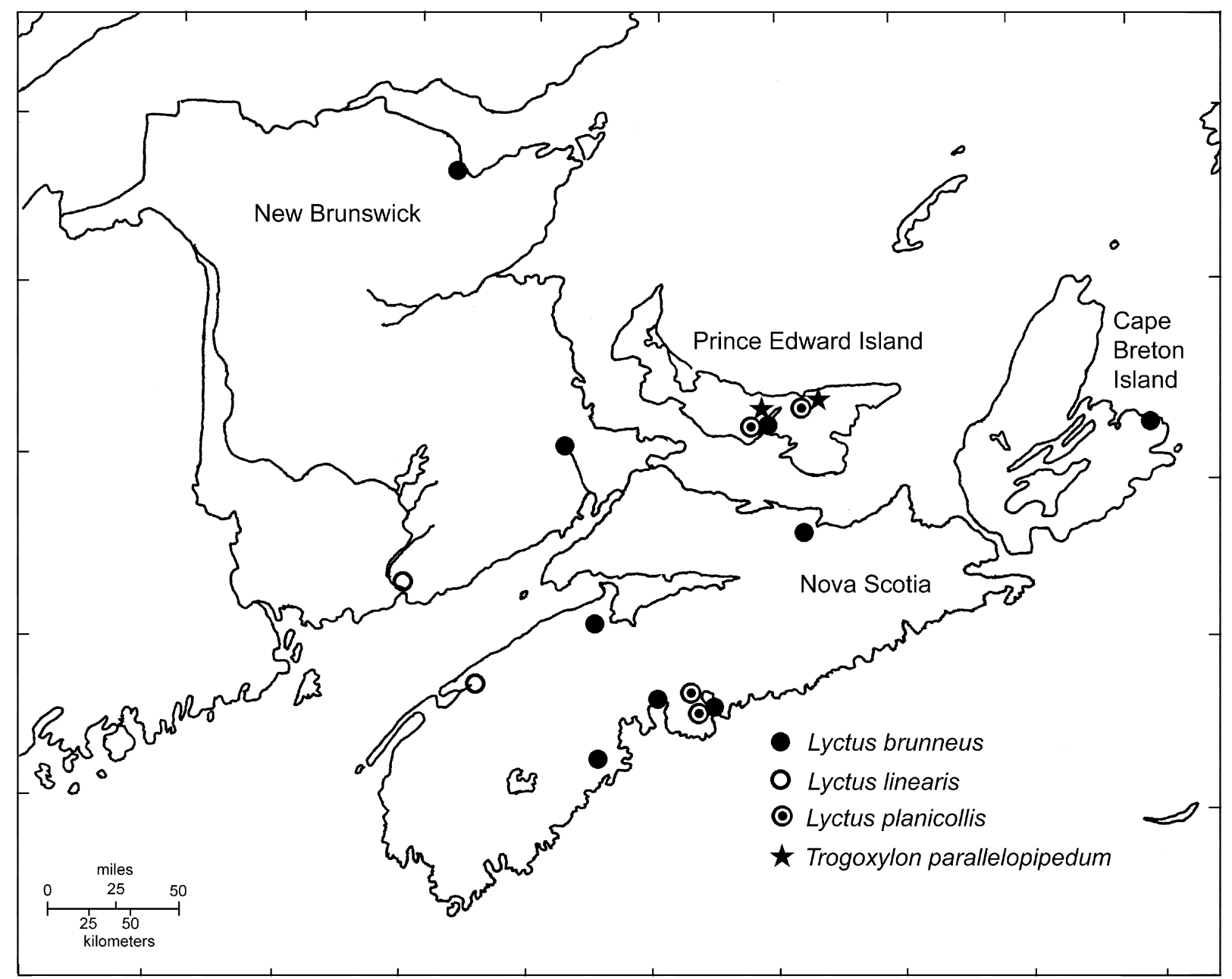

FIGURE 8. Distribution of Lyctus brunneus (Stephens), Lyctus linearis (Goeze), Lyctus planicollis LeConte, and Trogoxylon parallelopipedum (Melsheimer) in the Maritime Provinces of Canada.

\section{Trogoxylon parallelopipedum (Melsheimer, 1846)}

PRINCE EDWARD ISLAND: Queens Co.: Charlottetown, 4.i.1994, J.G. Stewart, in house, (2), ACPE; Mount Stewart, 29.i.1992, J.G. Stewart, ACPE.

An adventive species, possibly established in the region. Newly recorded on Prince Edward Island and in the Maritime Provinces as a whole (Fig. 8). A Nearctic species found in many parts of the United States (Gerberg 1957); in Canada recorded from Ontario (McNamara 1991b). It attacks seasoned hardwood timber, but has also been found boring into the trunks of living honey-locust (Gleditsia triacanthos L. (Fabaceae)) (Gerberg 1957). 


\section{ANOBIIDAE}

\section{Subfamily: Ptininae}

\section{Mezium affine Boieldieu, 1856}

NEW BRUNSWICK: Saint John Co.: Saint John, date not specified, M., CNC. NOVA SCOTIA: 36 specimens examined from Colchester, Antigonish, Halifax, Lunenburg, Yarmouth, and Kings counties (Table 1). The earliest record is from 1950 (Kings Co.: Kentville, 11.iv.1950, H.T. Stultz, ACNS). PRINCE EDWARD ISLAND: Queens Co.: Charlottetown, iv.1986, L.S. Thompson, (3), ACPE.

An introduced species, established in the region. Newly recorded on Prince Edward Island (Fig. 9). A cosmopolitan species found in Europe, Africa, North America, New Zealand, and elsewhere. In Canada recorded from British Columbia and Saskatchewan east to Nova Scotia. Feeds on dried stored products; occasionally found in warehouses and dwellings (Bousquet 1990).

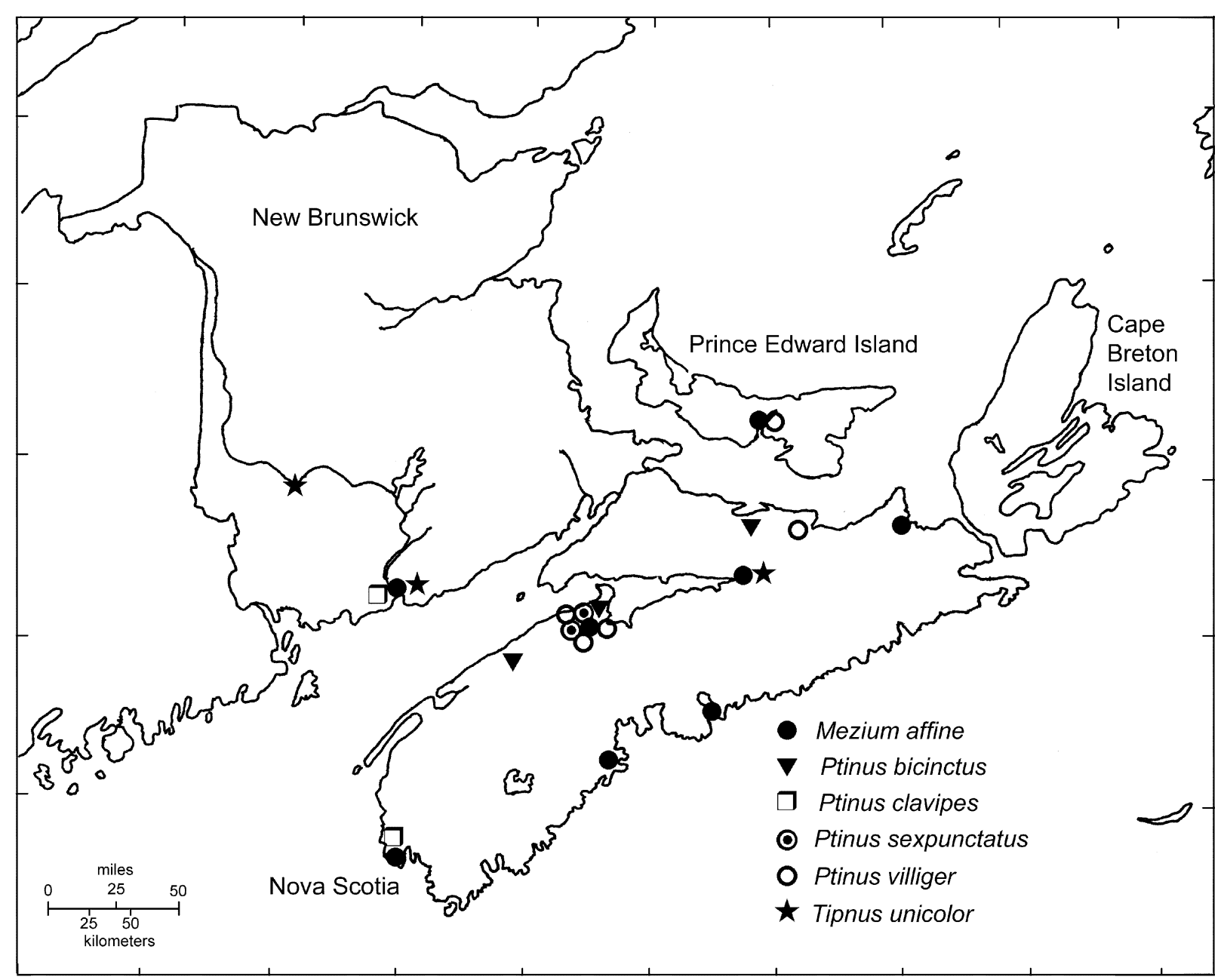

FIGURE 9. Distribution of Mezium affine Boieldieu, Ptinus bicinctus Sturm, Ptinus clavipes (Panzer), Ptinus sexpunctatus Panzer, Ptinus villiger (Reitter), and Tipnus unicolor (Piller \& Mitterpacher) in the Maritime Provinces of Canada.

Ptinus bicinctus Sturm, 1837

NOVA SCOTIA: Annapolis Co.: Middleton, 3.vi.1915, F.C. Gilliatt, ACNS; Colchester Co.: Balmoral Mills, 19.vi.1974, B. Wright, (2), NSMC; Kings Co.: Canning, 7.ix.1994, J. Ogden, JOC; Lunenburg Co.: 
Blockhouse, 4.v.1938, H.E. Gray, (2), CNC; Lunenburg, 4.v.1938, H.E. Gray, CNC; Richmond Co.: Cannes, 6.iv.1936, R.J. Boyd, (6), CNC.

An introduced species established in Nova Scotia (Fig. 9). The specimen collected in 1915 in Middleton, Nova Scotia is noteworthy, since this would appear to be the earliest record of this species in North America. The earliest previous records are specimens from Medicine Hat, Alberta, Canada (9.iv.1923, F.S. Carr, (2), CNC) reported by Brown (1940). Found throughout Europe and North Africa. Feeds on dried stored products; occasionally found in warehouses and dwellings (Bousquet 1990).

\section{Ptinus clavipes (Panzer, 1792)}

NEW BRUNSWICK: Saint John Co.: Saint John, 19.iv.1990, D.F. McAlpine, NBM. NOVA SCOTIA: Lunenburg Co.: Lunenburg, 4.v.1938, H.E. Gray, (10), CNC; Yarmouth Co.: Yarmouth, v.1999, H. Larkin, (2), NSNR.

An introduced species, possibly established in the region. Newly recorded in New Brunswick (Fig. 9). Cosmopolitan; in Canada recorded from British Columbia, Ontario, Québec, and Nova Scotia. Feeds on dried stored products; also found in nests of wasps, birds, and rats (Bousquet 1990).

\section{Ptinus fur (Linnaeus, 1758)}

NEW BRUNSWICK: Albert Co.: Mary's Pt., 24.xii.2001, C.G. Majka, in attic, CGMC; Mary's Pt., 15.xi.2005, D.S. Christie, in house, CGMC; Saint John Co.: Saint John, 1.v.1902, W. McIntosh, NBM; York Co.: Fredericton, 14.x.1987, N. Albert, UMNB. NOVA SCOTIA: 80 specimens examined from Cumberland, Colchester, Pictou, Cape Breton, Richmond, Halifax, Lunenburg, Shelburne, and Kings counties as well as Sable Island (Table 1). The earliest record is from 1922 (Colchester Co.: Truro, 23.vii.1922, (7), NSAC). PRINCE EDWARD ISLAND: Prince Co.: Summerside, 23.vi.1977, L.S. Thompson, ACPE; Queens Co.: Charlottetown, 11.ii.1982, L.S. Thompson, ACPE; Charlottetown, 11.xii.1995, M.E.M. Smith, ACPE; St. Patricks, 27.vi.2003, C.G. Majka, in cabin, CGMC; Mount Herbert, 18.ix.1924, J.R. Mutch, JRMC.

An introduced species, established in the region. Newly recorded on Prince Edward Island. Reported from Europe, North Africa, Asia, North America, and New Zealand. In Canada recorded from British Columbia east to Newfoundland (Bousquet 1990). Feeds on dried stored products; found in warehouses, dwellings, museums, granaries, and grain elevators (Bousquet 1990). In Europe sometimes found in bees' and wasps' nests (Howe and Burges 1951). Found in Newfoundland as early as 1620-70 (Prévost \& Bain 2006).

\section{Ptinus sexpunctatus Panzer, 1792}

This introduced European species was newly recorded in North America from specimens collected in Nova Scotia and Utah by Majka et al. (2007b). It has been found in nests of the native blue orchard mason bee, Osmia lignaria Say (Hymenoptera: Megachilidae).

\section{Ptinus villiger (Reitter, 1884)}

NOVA SCOTIA: Colchester Co.: Debert, 12.iv.1952, V.R. Vickery, NSAC; Kings Co.: Canard, 29.viii.1958, H.T. Stultz, ACNS; Canning, 7.ix.1994, J. Ogden, NSNR; Kentville, 6.viii.1957, 8.ix.1957, 
13.ix.1957, \& summer 1958, H.T. Stultz, (5), ACNS; Pictou Co.: Lyons Brook, 15.x.1998, E. Georgeson, NSNR. PRINCE EDWARD ISLAND: Queens Co.: Charlottetown, 25.iv.1990 \& 2.xi.1994, M.E.M. Smith, (3), ACPE; Charlottetown, xii.1990, J.G. Stewart, ACPE; Charlottetown, 16.viii.1982, L.S. Thompson, ACPE.

An introduced species, established in the region. Newly recorded on Prince Edward Island (Fig. 9). Found in Europe, Siberia, and North America. In Canada recorded from British Columbia east to Newfoundland. Feeds on damp grains and animal feed; found mainly in mills, granaries, and warehouses where flour is stored (Bousquet 1990).

\section{Subfamily: Ernobiinae}

\section{Tribe: Ernobiini}

Ernobius filicornis LeConte, 1879

NOVA SCOTIA: Queens Co.: Ponhook Lake, 13.vii.1993, J. Cook, ultra-violet light trap, JCC.

Newly recorded in Nova Scotia and in Canada as a whole (Fig. 10). Recorded from Ohio, Virginia, and Massachusetts (White 1982). Species of Ernobius are found in conifer cones and under bark (Philips 2002).

\section{Ernobius granulatus LeConte, 1865}

NOVA SCOTIA: Colchester Co.: Debert, 20.viii.1990, E. Georgeson, ultraviolet light trap, NSNR.

Newly recorded in Nova Scotia and in Canada as a whole (Fig. 10). Widely distributed in eastern North America from Maine south to Florida and Texas (White 1982, Chandler 2001, Sikes 2004). Abundant at ultraviolet lights (Downie \& Arnett 1996); larvae are found in conifer cones (White 1982).

\section{Ernobius mollis (Linnaeus, 1758)}

NEW BRUNSWICK: Saint John Co.: Saint John, 21.vii.1901, W. McIntosh, NBM. NOVA SCOTIA: 38 specimens examined from Colchester, Halifax, Lunenburg, Digby, and Kings counties (Table 1). The earliest record is from 1958 (Digby Co.: Bear River, 15.vii.1958, A.S. Riley, (3), ACNS). PRINCE EDWARD ISLAND: Queens Co.: Charlottetown, xii.1954, F.M. Cannon, ACPE; Charlottetown, 30.vii.1982, L.S. Thompson, (3), ACPE.

An introduced, Palearctic species newly recorded in New Brunswick and on Prince Edward Island (Fig. 10). Recorded from scattered states in the eastern United States from Maine south to Florida and Texas (White 1982, Downie \& Arnett 1996); in Canada known from Ontario, Québec, Nova Scotia, and Newfoundland (McNamara 1991c). Associated with pines (Pinus spp.); as a pest of wood products it is considered of minor importance (Peters et al. 1996).

\section{Ernobius schedli Brown, 1932}

NOVA SCOTIA: Digby Co.: Brier Island: Gull Rock Road, 21.vi.2003, J. Ogden \& K. Goodwin, light trap, JOC. 
Newly recorded in Nova Scotia (Fig. 10). In Canada known from Ontario, Québec, and Newfoundland (McNamara 1991c). Specific bionomics are unknown.

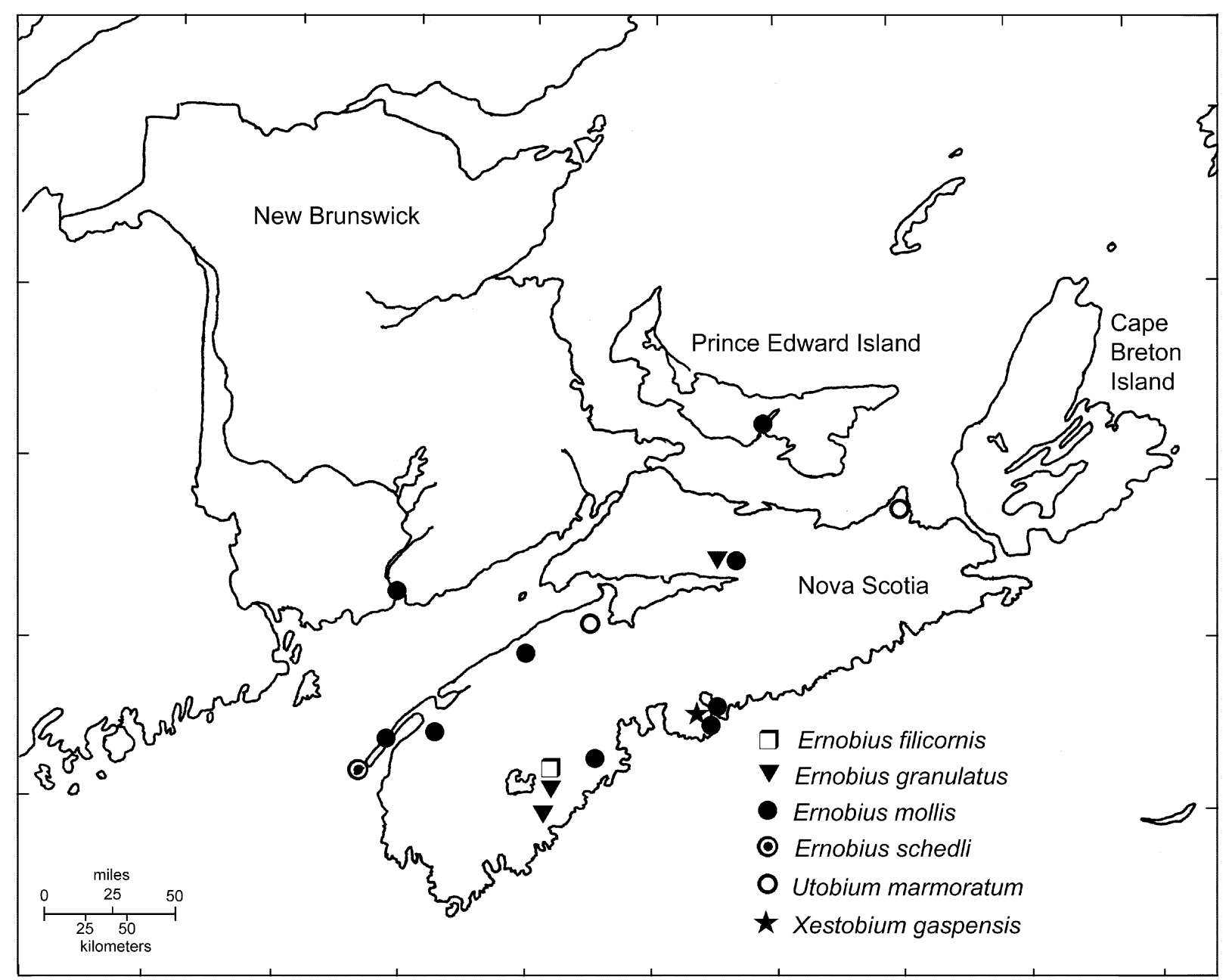

FIGURE 10. Distribution of Ernobius filicornis LeConte, Ernobius granulatus LeConte, Ernobius mollis (Linnaeus), Ernobius schedli Brown, Utobium marmoratum Fisher, and Xestobium gaspensis White in the Maritime Provinces of Canada.

\section{Tribe: Xestobiini}

Utobium marmoratum Fisher, 1939

NOVA SCOTIA: Antigonish Co.: Fairmont Tower, 29.vi.1995, M. Leblanc, funnel trap, NSNR; Kings Co.: Kentville, 12.vi.2002, D.H. Webster, DHWC.

Newly recorded in Nova Scotia and in the Maritime Provinces as a whole (Fig. 10). In Canada recorded from British Columbia (McNamara 1991c). Associated with pines (Pinus spp.) (Philips 2002).

\section{Xestobium gaspensis White, 1975}

NOVA SCOTIA: Halifax Co.: Point Pleasant Park, 27.vi.2000, B. Guscott, stovepipe trap, NSNR; Point Pleasant Park, 17.vi.2001, C.G. Majka, coniferous forest, CGMC; Point Pleasant Park, 17.vi.2001, C.G. 
Majka, coniferous forest, CGMC.

Newly recorded in Nova Scotia and in the Maritime Provinces as a whole (Fig. 10). Previously known only from Ontario and Québec (McNamara 1991c). Associated with balsam fir (Abies balsamaea) (White 1975).

\section{Subfamily: Anobiinae}

\section{Tribe: Anobiini}

\section{Hemicoelus carinatus (Say, 1823)}

NEW BRUNSWICK: Carleton Co.: Wakefield: Bell Forest Preserve, 22.vii.2004, K. Bredin, J. Edsall, \& R.P. Webster, hardwood forest, ultraviolet light, RPWC. NOVA SCOTIA: 25 specimens examined from Cumberland, Colchester, Antigonish, Inverness, Guysborough, Halifax, Lunenburg, Queens, Digby, Annapolis, and Kings counties (Table 1). The earliest record is from 1946 (Annapolis Co.: Lequille, 24.vi.1946, D.C. Ferguson, NSMC). PRINCE EDWARD ISLAND: Queens Co.: Charlottetown, 23.vii.1956, F.M. Cannon, (5), ACPE; North Rustico, 26.vi.2003, C.G. Majka, coastline, CGMC.

Newly recorded in Nova Scotia and Prince Edward Island (Fig. 11). Widely distributed in eastern North America from Maine south to North Carolina (White 1982, Downie \& Arnett 1996, Chandler 2001, Sikes 2004); in Canada recorded from British Columbia east to New Brunswick (McNamara 1991c). Common on softwood; frequent in woodwork, flooring, and structural wood of buildings (White 1982).

\section{Hemicoelus defectus (Fall, 1905)}

PRINCE EDWARD ISLAND: Prince Co.: Freetown, 25.vi.1972, D. Cairns, ultraviolet light trap, UPEI; Queens Co.: Cornwall, 15.iii.1985, M.E.M. Smith, ACPE; Cornwall, 15.iii.1987, L.S. Thompson, (5), ACPE. Newly recorded on Prince Edward Island and in the Maritime Provinces as a whole (Fig. 11). In the USA recorded from Massachusetts, Michigan, and Oregon (White 1982); in Canada recorded in British Columbia, Manitoba, Ontario, and Québec (McNamara 1991c). Species of Hemicoelus bore in the bark of many deciduous and coniferous trees (Philips 2002); found in oak stumps (White 1982).

\section{Microbregma emarginatum emarginatum (Duftschmid, 1825)}

NOVA SCOTIA: Antigonish Co.: Cape George Pt., 22.vi.1993 and 23.vi.1993, M. Leblanc, funnel trap, (2), NSNR; Colchester Co.: Masstown, 6.vi.1990, 21.vi.1990, and 29.vi.1990, T.D. Smith, stove pipe trap, (3), NSNR; North River, 15.vi.2005, J. Ogden, flight-intercept trap, NSNR; Truro, 18.vi.1993, J. Ogden, NSNR; Guysborough Co.: Sherbrooke, 2.vi.1984, J. Gilhen, NSMC; Halifax Co.: Point Pleasant Park, 28.vi.1990, R. Ballard, NSMC; Point Pleasant Park, 5.x.2000 and 17.vi.2001, C.G. Majka, (2) CGMC; south-end Halifax, 5.x.2000, C.G. Majka, garden, CGMC; Miller Lake, 11.vii.2005, no collector indicated, NSNR; Hants Co.: Panuke Lake, 16-29.vii.1997 and 29.vii-13.viii.1997, D.J. Bishop, old-growth red spruce-hemlock forest, flight-intercept trap, (2), NSMC; Smiley's Park, 22.vi.2004, D. MacDonald, NSNR; Lunenburg Co.: Card Lake, 1-16.vii.1997, D.J. Bishop, old-growth red spruce-hemlock forest, flight-intercept trap, NSMC; Chester, 6.vi.1968 and 17.vii.1969, B. Wright, (3), NSMC; Queens Co.: Sixth Lake, 11.vii.2003, P. Dollin, oldgrowth hemlock forest, funnel trap, NSMC. PRINCE EDWARD ISLAND: Kings Co.: Woodville Mills, 
26.xii.2001, C.G. Majka, under bark: Picea rubens, (4), CGMC.

An introduced, Palearctic species newly recorded in Nova Scotia, Prince Edward Island, and the Maritime Provinces as a whole (Fig. 11). In the USA recorded from Colorado, Maine, Massachusetts, Minnesota, Michigan, and New Hampshire, (White 1982; Dearborn \& Donahue 1993). In Canada recorded from British Columbia east to Québec (McNamara 1991c). Found under bark of pine, hemlock, and hickory (White 1982).

On Prince Edward Island found boring in Picea rubens Sarg. (Pinaceae).

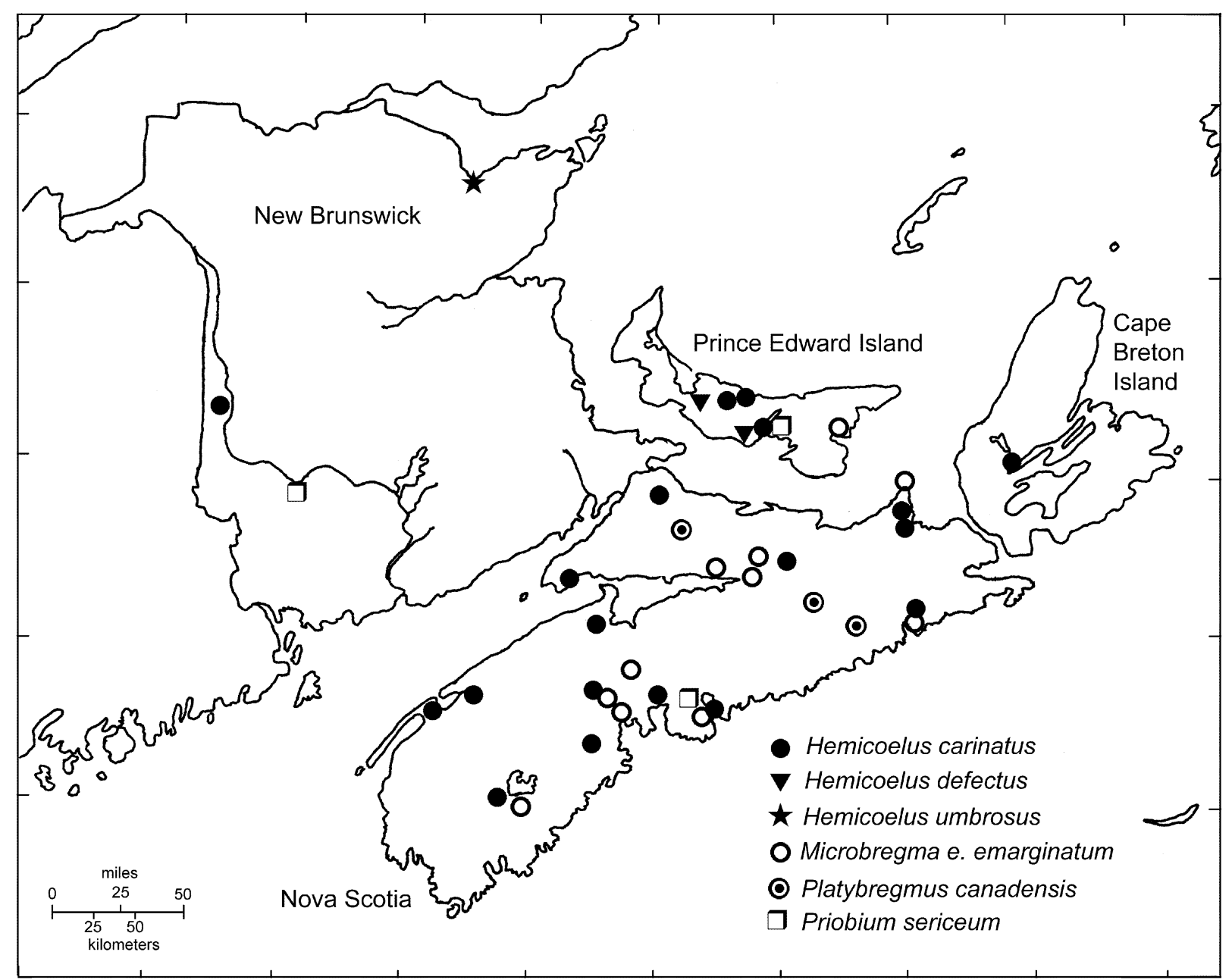

FIGURE 11. Distribution of Hemicoelus carinatus (Say), Hemicoelus defectus (Fall), Hemicoelus umbrosus (Fall), Microbregma e. emarginatum (Duftschmid), Platybregmus canadensis Fisher, and Priobium sericeum (Say) in the Maritime Provinces of Canada.

\section{Tribe: Hadrobregmini}

\section{Hadrobregmus notatus (Say, 1825)}

NOVA SCOTIA: 38 specimens examined from Cumberland, Colchester, Pictou, Antigonish, Victoria, Guysborough, Halifax, Lunenburg, Queens, Kings, and Hants counties (Table 1). The earliest record is from 1961 (Kings Co.: Cambridge Station, 13.v.1961, D.H. Webster, barnyard, DHWC). PRINCE EDWARD ISLAND: Queens Co.: Cornwall, 8.v.1983, L.S. Thompson, (3), ACPE; Cornwall, summer 1990, M.E.M. Smith, ACPE; St. Patricks, 27.vi.2003, C.G. Majka, coniferous forest, funnel trap, CGMC.

Newly recorded on Prince Edward Island (Fig. 12). In the USA recorded from Michigan, Ohio, Missis- 
sippi, and North Carolina (White 1982). In Canada recorded from Ontario, Québec, and Nova Scotia (McNamara 1991c). Found in dead and rotten oak, ash, chestnut, and pine and in pine boards (White 1982).

Priobium sericeum (Say, 1825)

NEW BRUNSWICK: York Co.: Fredericton, 16.vii.1928, W.J. Brown, CNC. NOVA SCOTIA: Cumberland Co.: Tatamagouche Park, 20.viii.2004, D. MacDonald, (2), NSNR; Halifax Co.: Halifax, 28.vii.1988, K. Dodge, (6), NSMC. PRINCE EDWARD ISLAND: Queens Co.: 6.vii.1982, L.S. Thompson, (2), ACPE.

Newly recorded on Prince Edward Island (Fig. 11). Widely distributed in the United States (White 1982, Downie \& Arnett 1996); in Canada recorded from Manitoba east to Nova Scotia (McNamara 1991c). Found in dead branches of oak, cherry, hickory, and holly; reared from dead mountain laurel (Kalmia latifolia L., Ericaceae); also found boring in flooring, woodwork, and furniture (White 1982).

Tribe: Stegobiini

Oligomerus sericans (Melsheimer, 1846)

NOVA SCOTIA: Halifax Co.: Waverley, 8.vi.1985, B. Wright, NSMC; Lunenburg Co.: Bridgewater, 1020.v.1965, B. Wright, (6), NSMC; Chester Grant, 21.v.1992, E. Georgeson, NSNR; Lunenburg, 23.vi.1996, J. Ogden, NSNR.

Newly recorded in Nova Scotia (Fig. 12). Widely distributed in the eastern and central United States (White 1982, Downie \& Arnett 1996); in Canada recorded from Ontario and Québec (McNamara 1991c). Found on English walnut, chestnut, and white oak (White 1982).

Stegobium paniceum (Linnaeus, 1758)

NEW BRUNSWICK: Saint John Co.: Saint John, 27.vii.1910, collector not recorded, in old cabinet, CNC. NOVA SCOTIA: 148 specimens examined from Colchester, Cumberland, Pictou, Cape Breton, Guysborough, Halifax, Lunenburg, and Kings counties (Table 1). The earliest record is from 1952 (Colchester Co.: Truro, 25.v.1952, M.E. Neary, (6), NSAC). PRINCE EDWARD ISLAND: Queens Co.: Charlottetown, v.1967 and v.1981, L.S. Thompson, (5), ACPE; Charlottetown, 10.x.1951 and xi.1955, F.M. Cannon, (2), ACPE; St. Patricks, 19.vii.2001, C.G. Majka, cabin, CGMC.

An introduced Palearctic species newly recorded in Nova Scotia and on Prince Edward Island (Fig. 12). Cosmopolitan; in Canada recorded from British Columbia east to Newfoundland (McNamara 1991c). Found in mills, bakeries, warehouses, libraries, and homes where the larvae feed on a wide variety vegetable and animal products as well as dried plants, old books, and paper.

\section{Subfamily: Ptilininae}

Tribe: Ptilinini

Ptilinus lobatus Casey, 1898

NOVA SCOTIA: Lunenburg Co.: Laconia, 4.vii.2002, P. Churchill, in poplar logs, NSNR. 
Newly recorded in Nova Scotia and the Maritime Provinces as a whole (Fig. 13). Recorded in Canada from British Columbia and the Yukon east to Ontario (McNamara 1991c). Larvae mine in hardwoods (Philips 2002). In Nova Scotia found in Populus logs.

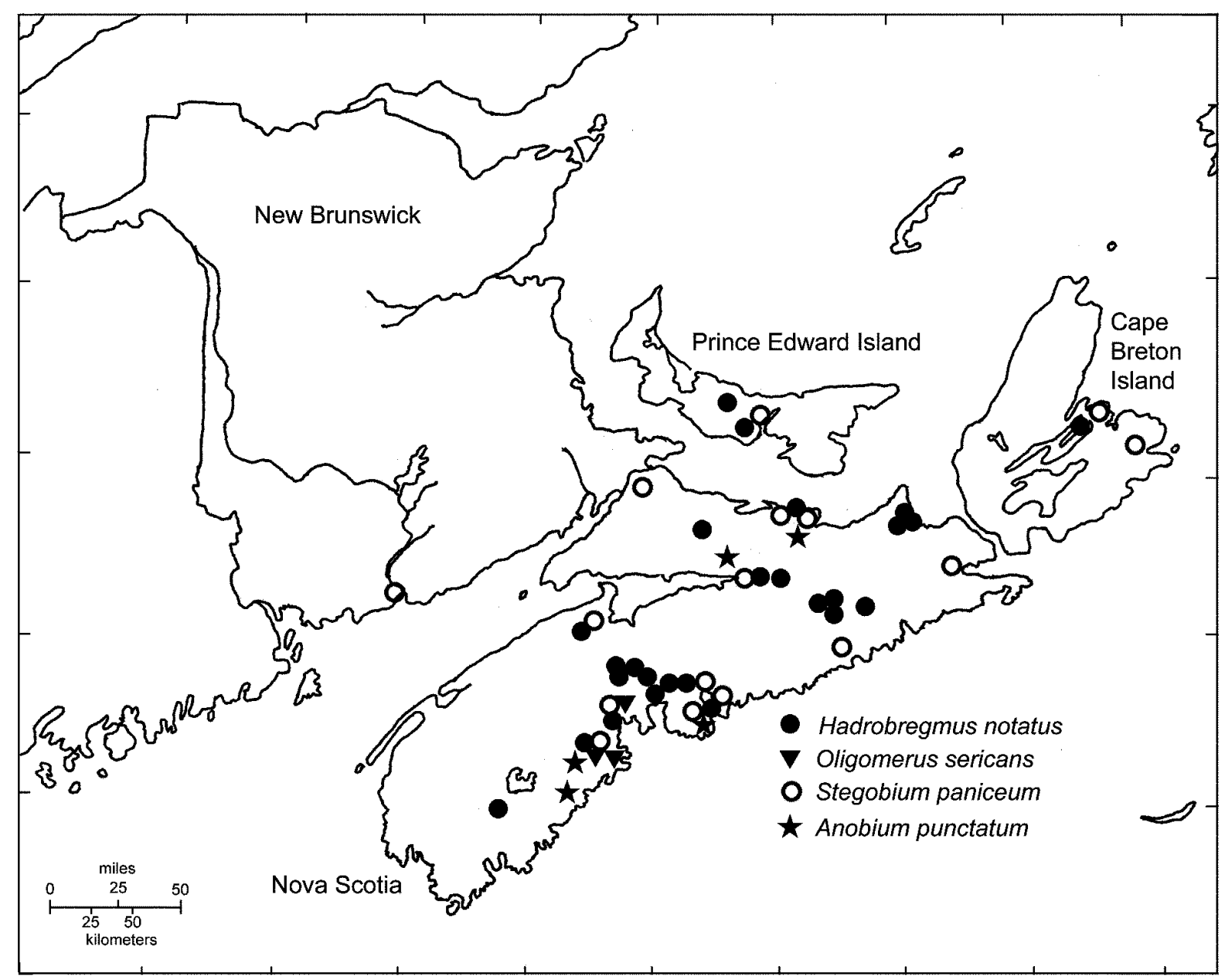

FIGURE 12. Distribution of Hadrobregmus notatus (Say), Oligomerus sericans (Melsheimer), Stegobium paniceum (Linnaeus), and Anobium punctatum (DeGeer) in the Maritime Provinces of Canada.

\section{Ptilinus pruinosus Casey, 1898}

NOVA SCOTIA: Lunenburg Co.: Mahone Bay, 26.vi.1995, J. Macphee, NSNR.

Newly recorded in Nova Scotia (Fig. 13). This species was recorded from New Brunswick by (McNamara 1991c). No specimens from the province in any collection were located, nor are there published records which would authenticate the report. Consequently the species is removed from the faunal list of New Brunswick. Otherwise recorded in Canada from Manitoba, Ontario, and Québec (McNamara 1991c). Larvae mine in hardwoods (Philips 2002). 


\section{Subfamily: Xyletininae}

\section{Tribe: Xyletinini}

\section{Euvrilletta peltata (Harris, 1836)}

PRINCE EDWARD ISLAND: Queens Co.: 14.vii.2002, C.G. Majka, along small stream, CGMC.

Newly recorded on Prince Edward Island and in the Maritime Provinces as a whole (Fig. 13). Widely distributed in the eastern USA (White 1982). In Canada recorded from Manitoba, Ontario, and Québec (McNamara 1991c). Frequent at ultraviolet lights (Downie \& Arnett 1996). Found boring in woodwork and in hardwoods and softwoods (White 1982).

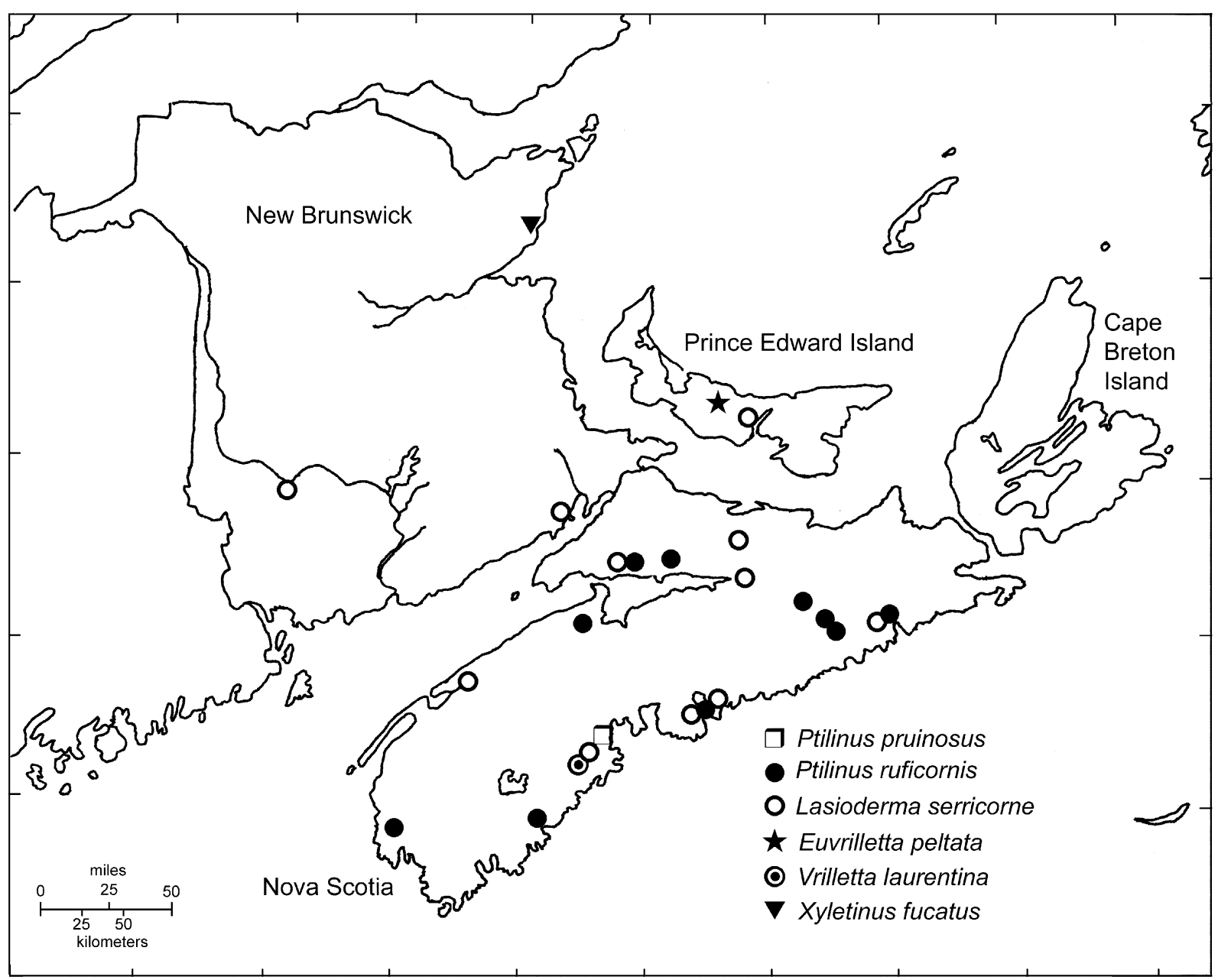

FIGURE 13. Distribution of Ptilinus pruinosus Casey, Ptilinus ruficornis Say, Lasioderma serricorne (Fabricius), Euvrilletta peltata (Harris), Vrilletta laurentina Fall, and Xyletinus fucatus LeConte in the Maritime Provinces of Canada.

\section{Vrilletta laurentina Fall, 1905}

NOVA SCOTIA: Lunenburg Co.: Bridgewater, 19.vi.1965, B. Wright, window trap in red oak, NSMC.

Newly recorded in Nova Scotia and in the Maritime Provinces as a whole (Fig. 13). In the USA recorded from New York and Pennsylvania (Downie \& Arnett 1996); in Canada from Ontario and Québec (McNamara 
1991c). Found on the bark of a decaying basswood tree (Downie \& Arnett 1996). Vrilletta species have been recorded on oak, linden, and alder (Philips 2002).

\section{Tribe: Lasiodermini}

\section{Lasioderma serricorne (Fabricius, 1792)}

NEW BRUNSWICK: Albert Co.: Mary's Point, 13.i.2003, D.S. Christie, in house, (2), CGMC; York Co.: Fredericton, 26.ix.1987, N. Albert, UMNB. NOVA SCOTIA: 22 specimens examined from Cumberland, Colchester, Guysborough, Halifax, Lunenburg, and Annapolis counties (Table 1). The earliest record is from 1929 (Annapolis Co.: Annapolis Royal, 9.viii.1929, F.C. Gilliatt, (2), ACNS). PRINCE EDWARD ISLAND: Queens Co.: Charlottetown, 30.x.1985, L.S. Thompson, (2), ACPE; Charlottetown, 28.vii.1987, M.E.M. Smith, (6), ACPE.

Newly recorded in New Brunswick, Nova Scotia, Prince Edward Island, and in the Maritime Provinces as a whole (Fig. 13). Cosmopolitan, particularly in tropical and semi-tropical regions; in Canada recorded from Alberta, Manitoba, Ontario, and Québec (McNamara 1991c). A pest of stored tobacco products, it also occurs in dwellings and stores where it feeds on a wide variety of foods and drugs and is known to attack insect and plant collections (Bousquet 1990). White (1975) suggested that thistles were the ancestral host plant of the species.

\section{Subfamily: Dorcatominae}

\section{Tribe: Dorcatomini}

Byrrhodes intermedius (LeConte, 1878)

NOVA SCOTIA: Lunenburg Co.: Bridgewater, 6.vii.2004, G.D. Selig, GSC.

Newly recorded in Nova Scotia and in the Maritime Provinces as a whole (Fig. 14). In the USA recorded from New Hampshire south to Florida and west to Michigan (White 1982, Downie \& Arnett 1996, Chandler 2001); in Canada from Québec (McNamara 1991c). Associated with the polypore, Fomes fomentarius (L. ex Fr.) Kickx (Polyporaceae) (White 1982).

\section{Caenocara oculata (Say, 1824)}

NOVA SCOTIA: 26 specimens examined from Cumberland, Guysborough, Halifax, Queens, Yarmouth, and Kings counties (Table 1.) The earliest record is from 1970 (Halifax Co.: Tomahawk Lake, 6.vi.1970, P. Doleman \& J. Gilhen, NSMC).

This species was recorded from New Brunswick by (McNamara 1991c). No specimens from the province in any collection were located nor are there published records which would authenticate the report. Consequently the species is removed from the faunal list of New Brunswick, although it is likely to occur there. Otherwise known from Ontario, Québec, and Nova Scotia (McNamara 1991c) (Fig. 14). Larvae live in puffballs (Lycoperdon spp., Lycoperdales) (White 1982, Philips 2002). 


\section{Dorcatoma falli White, 1965}

NOVA SCOTIA: Halifax Co.: Sandy Lake, 1-16.vii.1997, D.J. Bishop, old-growth red spruce forest, flightintercept trap, NSMC; Hants Co.: Leminister, 1-16.vii.1997, D.J. Bishop, red spruce-hemlock forest, flightintercept trap, NSMC; Panuke Lake, 1-16.vii.1997, D.J. Bishop, old-growth red spruce-hemlock forest, flightintercept trap, (3), NSMC; Lunenburg Co.: Card Lake, 16-29.vii.1997, D.J. Bishop, old-growth red spruce forest, flight-intercept trap, NSMC; Queens Co.: Sixth Lake, 11.vii.2003, P. Dollin, old-growth hemlock forest, sweeping, NSMC.

Newly recorded in Nova Scotia and the Maritime Provinces as a whole (Fig. 14). Recorded in the USA in Montana, Missouri, Maryland, and South Carolina (White 1982); in Canada known from Ontario (McNamara 1991c). Associated with woody fungi including Fistulina hepatica (Schaeff. ex Fr.), Ganoderma spp., and Elfingia spp. (Polyporaceae) (White 1982, Philips 2002). It is noteworthy that almost all specimens were collected in old-growth coniferous forests.

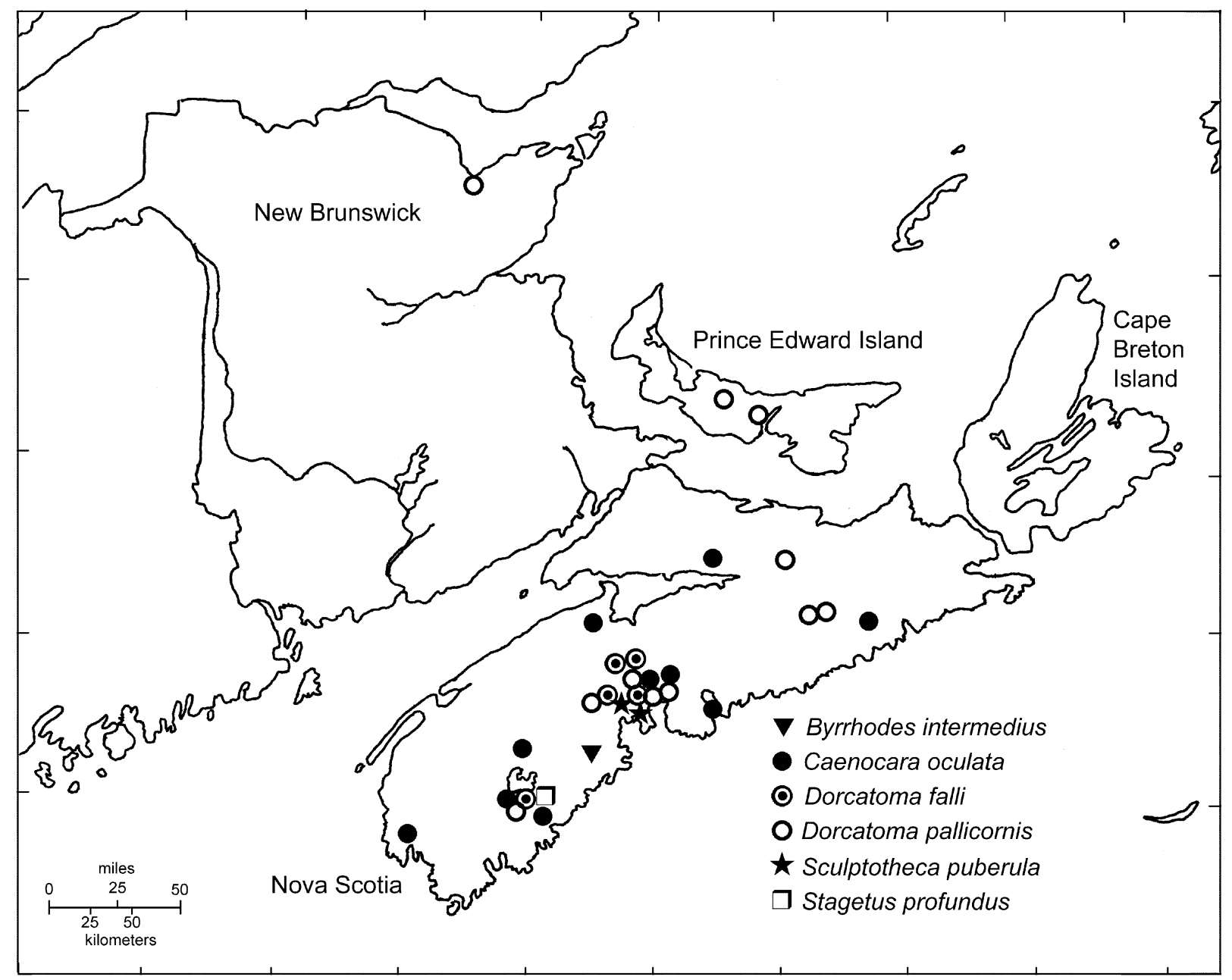

FIGURE 14. Distribution of Byrrhodes intermedius (LeConte), Caenocara oculata (Say), Dorcatoma falli White, Dorcatoma pallicornis LeConte, Sculptotheca puberula (LeConte), and Stagetus profundus (LeConte) in the Maritime Provinces of Canada.

\section{Dorcatoma pallicornis LeConte, 1874}

NEW BRUNSWICK: Gloucester Co.: Bathurst, 15.vii.1939, W.J. Brown, CNC. NOVA SCOTIA: 
Colchester Co.: Kemptown, 13.vii.1995, C. Corkum, young deciduous forest, NSMC; Halifax Co.: Anti Dam Lake, 15-30.vi.1997, D.J. Bishop, black spruce forest, flight-intercept trap, NSMC; Big Indian Lake, 8.vii.2003, P. Dollin, red spruce forest, (2), NSMC; Big St. Margaret's Bay, 1-26.vii.1997 and 16-29.vii.1997, D.J. Bishop, old-growth red spruce forest, flight-intercept trap, (2), NSMC; Campbell Hill, 1-16.vii.1997, D.J. Bishop, red spruce forest, flight-intercept trap, NSMC; Ten Mile Lake, 29.vii-13.viii.1997, D.J. Bishop, red spruce forest, flight-intercept trap, NSMC; Hants Co.: Nine Mile River, 16-29.vii.1997, D.J. Bishop, young black spruce forest, flight-intercept trap, NSMC; Pictou Co.: Waterside, 11.viii.2004, D. MacDonald, NSNR; Queens Co.: Sixth Lake, 14.vii.2003, P. Dollin, old-growth hemlock forest, sweeping, NSMC. PRINCE EDWARD ISLAND: Queens Co.: East Royalty, 8.vii.1986, M.E.M. Smith, hedgerow beside forest, ACPE; St. Patricks, 25.vi.2003, C.G. Majka, mixed forest, CGMC.

Newly recorded in Nova Scotia (Fig. 14). Widely distributed in the northeastern USA (Downie \& Arnett 1996, Chandler 2001); in Canada recorded from Saskatchewan east to Newfoundland. Dorcatoma species feed on woody fungi (Philips 2002). In the Maritime Provinces collected in a variety of primarily coniferous forested habitats ranging in age from young to old-growth.

\section{Tribe: Prothecini}

Sculptotheca puberula (LeConte, 1865)

NOVA SCOTIA: Halifax Co.: Big St. Margaret's Bay, 29.vii-13.viii.1997, D.J. Bishop, old-growth red spruce forest, flight-intercept trap, NSMC; Hants Co.: Panuke Lake, 29.vii-13.viii.1997, D.J. Bishop, oldgrowth red spruce-hemlock forest, flight-intercept trap, NSMC.

Newly recorded in Nova Scotia and the Maritime Provinces as a whole (Fig. 14). In the USA recorded from Vermont south to Florida and Texas (White 1982, Chandler 2001); in Canada from Ontario and Québec (McNamara 1991c). Attracted to ultraviolet lights (Downie \& Arnett 1996). Bionomics are unknown.

\section{Stagetus profundus (LeConte, 1865)}

NOVA SCOTIA: Queens Co.: Medway River, 18.vii.1993, J. \& T. Cook, car-netting, JCC.

Newly recorded in Nova Scotia and the Maritime Provinces as a whole (Fig. 14). In the USA recorded from Pennsylvania and Maryland west to Indiana and in Washington and Oregon (White 1982; Downie \& Arnett 1996); in Canada from British Columbia, Ontario, and Québec (McNamara 1991c). The bionomics are unknown.

\section{Discussion}

As a result of the present research, the regional fauna of Derodontidae, Dermestidae, Bostrichidae, and Anobiidae is now known to be much more diverse than had been previously supposed. Seventy-four species are found in the Maritime Provinces, including 30 found in New Brunswick, 65 in Nova Scotia, and 29 on Prince Edward Island. Seven species are newly recorded from New Brunswick, 24 from Prince Edward Island, and 37 from Nova Scotia for a total of 68 new provincial records. Thirty species are newly recorded in the Maritime Provinces as a whole, three of which, Dinoderus minutus, Ernobius filicornis, and Ernobius granulatus, are newly recorded in Canada. Six other exotic species have been intercepted at ports and points in the region. Two species, Ptilinus pruinosus and Caenocara oculata, are removed from the faunal list of New Brunswick and one subspecies, Attagenus unicolor unicolor, is removed from the faunal list of Prince Edward Island. 
Thirty-four of the 74 species found in the Maritime Provinces (46\%) are non-native, introduced species, more than triple the proportion (15.1\%) of introduced species of Coleoptera found in Nova Scotia overall (C.G. Majka, unpublished data). Three other species, Reesa vespulae, Lyctus planicollis, and Trogoxylon parallelopipedum, while being Nearctic species, are synanthropic and have been introduced to the region. Thus a total of 37 species (plus one additional subspecies) have been introduced to the Maritime Provinces - 50\% of the regional fauna. Additionally six other exotic species have been intercepted at ports and points in the region.

Atlantic Canada has long been known as an area with a large number of introduced species and this group of families are distinguished by having very high proportions of them. Majka and McCorquodale (2006) found 6 of 50 species of Coccinellidae (12\%) in the Maritime Provinces to be introduced while Majka et al. (2007a) found 60 of 289 (21\%) of weevils (Curculionoidea) were introduced species. Majka et al. (2006) reported $12.3 \%$ of the species of Carabidae found in Nova Scotia and $15.1 \%$ of those found on Prince Edward Island were introduced species. Amongst the saproxylic Tetratomidae, Melandryidae, Synchroidae, Scraptidae, Mycteridae, Boridae, Pythidae, Pyrochroidae, and Salpingidae, Majka and Pollock (2006) and Majka (2006) found no introduced species in the region.

Although Laricobius erichsonii was introduced deliberately for biocontrol purposes, the other 33 species were apparently introduced inadvertently as a result of commerce and other related activities. Some of these including Dermestes lardarius, Attagenus pellio, A. unicolor japonicus, Anthrenus fuscus, A. scrophulariae, Lyctus brunneus, Mezium affine, Ptinus bicinctus, P. fur, P. raptor, Ernobius mollis, Microbregma e. emarginatum, Stegobium paniceum, and Lasioderma serricorne have become widespread within the region (Table 1). Other species have much more restricted distributions around the loci where they were introduced. Species such as Dermestes frischii (last recorded in 1961), Dermestes maculatus (only recorded in 1975), Thylodrias contractus (only recorded in 1978), Attagenus u. unicolor (only recorded in 1992), Trogoderma variable (only recorded in 1978), Dinoderus minutus (only recorded in 1988), Lyctus linearis (last recorded in 1932), Gibbium psylloides (last recorded in 1985), Niptus hololeucus (last recorded in 1955), Pseudeurostus hilleri (last recorded in 1938), and Tipnus unicolor (only recorded in 1938) probably represent transient introductions of species which may no longer be extant in the region. The six non-established species intercepted in this region (Table 1) illustrate that the processes which lead to introductions of exotics are on-going and continue to bring new species to the Maritime Provinces.

Many of these introduced species are synanthropic, and in this region exist solely in human habitations and in other man-made structures and situations where their food sources are found and where they are able to survive. Other species such as Dermestes lardarius, Anthrenus fuscus, A. verbasci, and Anobium punctatum have to varying degrees colonized natural environments, while Laricobius erichsonii, Ernobius mollis, and Microbregma e. emarginatum are found exclusively in natural habitats.

Table 2 summarizes the earliest recorded dates of occurrence of these introduced species in the Maritime Provinces as well as (when such information could be determined) the earliest recorded dates and locations of occurrence of these species in North America. It is noteworthy that at least eight of these species, Laricobius erichsonii, Attagenus pellio, A. unicolor japonicus, Niptus hololeucus, Ptinus fur, Ptinus raptor, Ptinus sexpunctatus, and Tipnus unicolor, were first recorded in North America in Atlantic Canada, a finding in keeping with the long history of Coleoptera introduced to this region (Lindroth 1957; Brown 1940, 1950, 1967; and many subsequent papers). While early writers on Coleoptera in the region such as Kirby (1837) and Jones (1869) had already noted the presence of introduced Coleoptera in the 19th century, recent archeological research by Prévost and Bain (2006) has found evidence of some of these species from the 17th century, substantially revising introduction timelines and altering our understanding of the history and dispersal of these adventive species in North America.

Although the mean year of first discovery of introduced species is 1939 in New Brunswick, 1950 in Nova Scotia, and 1976 in Prince Edward Island, the lack of early collecting for many of these species, and the substantial differences in collecting effort between the three provinces, mean that little can presently be concluded from this information. 
TABLE 2. Earliest recorded dates of detection of introduced species.

\begin{tabular}{lllllll}
\hline Species & NB & NS & PEI & $\begin{array}{l}\text { North } \\
\text { America }\end{array}$ & Location & Source \\
\hline $\begin{array}{l}\text { DERODONTIDAE } \\
\text { Laricobius erichsonii Rosenhauer }\end{array}$ & 1951 & 1954 & 1951 & New Brunswick & Clark and Brown (1958)
\end{tabular}

\section{DERMESTIDAE}

Dermestes frischii Kugelann

Dermestes lardarius Linnaeus

Dermestes maculatus DeGeer

Dermestes undulatus Brahm

Thylodrias contractus Motshulsky

Attagenus pellio (Linnaeus)

Attagenus u. unicolor (Brahm)

Attagenus unicolor japonicus Reit- 1901 ter

Anthrenus fuscus Olivier

Anthrenus museorum (Linnaeus)

Anthrenus scrophulariae (Lin- 1928 naeus)

Anthrenus verbasci (Linnaeus)

Trogoderma variable Ballion

\section{BOSTRICHIDAE}

Dinoderus minutus (Fabricius)

Rhyzopertha dominica (Fabricius)

Lyctus brunneus (Stephens)

Lyctus linearis (Goeze)

\section{ANOBIIDAE}

Gibbium psylloides (Czempinski)

Mezium affine Boieldieu

Niptus hololeucus (Faldermann)

Ptinus bicinctus Sturm

Ptinus clavipes (Panzer)

Ptinus fur (Linnaeus)

Ptinus ocellus Brown

Ptinus raptor Sturm

Ptinus sexpunctatus Panzer

Ptinus villiger (Reitter)

Pseudeurostus hilleri (Reitter)

1878
2003
1992
1901

1958

1827

1982

2002

1978

1827

$1970 \sim 1670$

$1975 ?$

02

$$
<1837
$$

Ontario

1902

1827

$?$

$\begin{array}{lll}1950 & 1960 \quad 1870\end{array}$

196119931907

19961983 ?

$1948 \quad 1971 \quad 1855$

1948

$1978 \quad 1935$

1988

1975

1995

$?$

1861

$1984 \quad 1976 \quad 1983$ ?

$1900 \quad 1932$

$?$

New York

Québec

New York
USA \& QC

Massachusetts Bain (1998)

Nova Scotia

New Hampshire

Beal (1983)

Kirby (1837)

Slosson (1903)

Kirby (1837)

Bain (1999)

R.S. Beal (pers. com.)

R.S. Beal (pers. com.)

LeConte (1862) \& Bain (1999)

$\begin{array}{llllll} & 1985 & & 1889 & \text { USA } & \text { Fauvel (1889) } \\ <1940 & 1950 & 1986 & 1904 & \text { Northeastern USA } & \text { Brown (1944) } \\ 1938 & 1899 & 1955 & 1899, & \text { Nova Scotia, } & \text { Brown (1940), } \\ & & & \sim 1890 & \text { Québec } & \text { Bain (1999) } \\ & 1915 & & 1915 ? & \text { Nova Scotia } & \text { present study } \\ 1990 & 1938 & & <1905 & \text { USA } & \text { Fall (1905) } \\ 1902 & 1912 & 1977 & \sim 1620-70 & \text { Newfoundland } & \text { Prévost \& Bain (2006) } \\ & 1969 & & 1927 & \text { British Columbia } & \text { Brown (1940) } \\ 1981 & 1930 & & 1930 & \text { Nova Scotia } & \text { Brown (1940) } \\ & 2003 & & 2003 & \text { Nova Scotia } & \text { Majka } \text { et al. }(2007 b) \\ & 1952 & 1982 & 1905 & \text { USA } & \text { Fall (1905) } \\ 1938 & & & 1936 & \text { Québec } & \text { Brown (1940) }\end{array}$




\begin{tabular}{|c|c|c|c|c|c|c|}
\hline Species & NB & NS & PEI & $\begin{array}{l}\text { North } \\
\text { America }\end{array}$ & Location & Source \\
\hline $\begin{array}{l}\text { Tipnus unicolor (Piller \& Mitter- } \\
\text { pacher) }\end{array}$ & 1938 & 1938 & & $<1620$ & Newfoundland & Prévost \& Bain (2006) \\
\hline Ernobius mollis (Linnaeus) & 1901 & 1958 & 1954 & 1846 & Pennsylvania & Melsheimer (1846) \\
\hline Anobium punctatum (DeGeer) & & 1970 & & 1865 & New Jersey & LeConte (1865) \\
\hline $\begin{array}{l}\text { Microbregma } \\
\text { (Duftschmid) }\end{array}$ & 1968 & 2001 & 1837 & Canada & Kirby (1837) & \\
\hline Stegobium paniceum (Linnaeus) & 1910 & 1952 & 1951 & 1825 & ? & Say (1825) \\
\hline Lasioderma serricorne (Fabricius) & 1987 & 1929 & 1985 & 1886 & USA & Howe (1957) \\
\hline mean year of discovery & 1939 & 1950 & 1976 & 1865 & & \\
\hline
\end{tabular}

Note: NB, New Brunswick; NS, Nova Scotia; PEI, Prince Edward Island. <, = prior to; , approximately

With regard to the indigenous, native fauna of the region, it consists of 37 species (excluding the adventive Reesa vespulae, Lyctus planicollis, and Trogoxylon parallelopipedum), 36 of which are Nearctic and one, Stephanopachys substriatus, is a Holarctic species. A few of these species appear widely distributed and have been recorded from a substantial number of records. These include Anthrenus castaneae, Trogoderma inclusum, Hemicoelus carinatus, Hadrobregmus notatus, Ptilinus ruficornis, and Caenocara oculata. Many others, however, are represented by a small number of specimens from a limited number of locations. Twentytwo of these (60\%) including Derodontus esotericus, Derodontus maculatus, Dermestes pulcher, Lichenophanes bicornis, Prostephanus punctatus, Stephanopachys rugosus, Stephanopachys substriatus, Ernobius filicornis, Ernobius granulatus, Ernobius schedli, Utobium marmoratum, Xestobium gaspensis, Hemicoelus umbrosus, Platybregmus canadensis, Ptilinus lobatus, Ptilinus pruinosus, Euvrilletta peltata, Vrilletta laurentina, Xyletinus fucatus, Byrrhodes intermedius, Sculptotheca puberula, and Stagetus profundus have been recorded in the region from less than ten specimens. This apparent scarcity could be due to a) insufficient collecting; b) the ecology of the species, which are not readily collected by the techniques which have been used to sample species in the region; or c) to a genuine scarcity.

Majka \& Pollock (2006) and Majka (2006) identified 11 species of "rare" saproxylic beetles and speculate that their apparent scarcity could be indicative of a diminution of appropriate habitats as a result of a long history of forest management practices. For instance, in Nova Scotia although $73 \%$ of the land base is forested, no more than $0.6 \%$ of that land is comprised of old-growth forests, much in a highly fragmented condition (McMahon 1989; Loo \& Ives 2003). Wood-boring and other saproxylic species, such as those in the Bostrichidae and Anobiidae, could potentially be affected by forest management practices that alter the quantity and composition of dead wood in forests. In Great Britain Alexander (2004) includes nine species of anobiids, one bostrichid, and two dermestids in the calculation of the Index of Ecological Continuity (an inverse of disturbance), an indication that these species are highly vulnerable to disturbance. The 22 apparently scarce species listed above are all potential candidates in terms of being genuinely rare in the region. They therefore deserve further attention to determine their status and vulnerability in the region.

As is typically the case with island faunas, the number of native species found on Prince Edward Island (8 species) is diminished, consisting of only $22 \%$ of the mainland fauna. Cape Breton Island - with a land area slightly more than twice the size of Prince Edward Island $\left(10,311 \mathrm{~km}^{2} \mathrm{vs.} 5,660 \mathrm{~km}^{2}\right)$, and separated from the mainland by only $1.5 \mathrm{~km}$ (in contrast to the $13 \mathrm{~km}$ which separate New Brunswick and Prince Edward Island) - nonetheless has an identically-sized native fauna (8 species) as that of Prince Edward Island. These may represent island-associated diminutions, the paucity of collecting, or a combination of both factors. These proportions are less than those of native Coccinellidae found on Prince Edward Island (39\%) and Cape Breton (41\%) 
by Majka and McCorquodale (2006), and of Tetratomidae, Melandryidae, Synchroidae, and Scraptiidae found on Prince Edward Island (27\%) and Cape Breton (32\%) by Majka and Pollock (2006). It is nevertheless noteworthy that within the region Hemicoelus defectus and Euvrilletta peltata have only been found on Prince Edward Island, and Derodontus esotericus, Derodontus maculatus, and Lichenophanes bicornis have only been found on Cape Breton Island.

\section{Acknowledgments}

Thanks are extended to Susan Westby (Agriculture and Agri-Food Canada, Kentville), Christine Noronha and Mary Smith (Agriculture and Agri-Food Canada, Charlottetown), Yves Bousquet (Agriculture and Agri-Food Canada, Ottawa), David McCorquodale (Cape Breton University), Philana Dollin (Dalhousie University), David H. Webster, Joyce Cook (Carleton University), Andreas Herrmann (Dermestidae.com), Jeff Ogden (Nova Scotia Department of Natural Resources), David Christie (New Brunswick Federation of Naturalists), Donald McAlpine (New Brunswick Museum), DeLancey Bishop (North Mountain Old Forest Society), JeanPierre Le Blanc (Nova Scotia Agricultural College), Chantelle Cormier (Saint Mary's University), Pauline Duerr (Université de Moncton), Donna Giberson (University of Prince Edward Island), Gary Selig, and Reginald P. Webster for making specimens and records available. Particular thanks to Yves Bousquet, Richard Beal, and Keith Philips (Western Kentucky University) for their generous assistance in regard to many matters. Thanks also to David Christianson, Calum Ewing, and Andrew Hebda at the Nova Scotia Museum for their support and encouragement. This work has been assisted by the Board of Governors of the Nova Scotia Museum.

\section{References}

Alexander, K.N.A. (2004) Revision of the Index of Ecological Continuity as used for saproxylic beetles. English Nature Research Report 574, Peterborough, England, 60 pp.

Bain, A. (1998) A seventeenth-century beetle fauna from colonial Boston. Historical Archeology, 32(3), 38-48.

Bain, A. (1999) Archeoentomological and archeoparasitological reconstructions at Îlot Hunt (CeEt-110): new perspectives in historical archeology (1850-1900). Unpublished Ph.D. thesis, University of Laval, Québec, 310 pp.

Beal, R.S., Jr. (1967) A revisionary study of the North American dermestid beetles formerly included in the genus Perimegatoma. Miscellaneous Publications of the Entomological Society of America, 5, 281-312.

Beal, R.S., Jr. (1983) Anthrenus thoracicus (Coleoptera: Dermestidae), a distinct species. The Coleopterists Bulletin, 37(4), 314-316.

Beal, R.S., Jr. (2003) Annotated checklist of Nearctic Dermestidae with revised key to the genera. The Coleopterists Bulletin, 57(4), 391-404.

Bright, D.E. (1991) Family Derodontidae: tooth-necked fungus beetles. In Bousquet, Y. (Ed.) Checklist of Beetles of Canada and Alaska. Agriculture Canada: Research Branch, Publication 1861/E, pp. 195-196.

Brown, W.J. (1940) Notes on the American distribution of some species of Coleoptera common to the European and North American continents. The Canadian Entomologist, 72, 65-78.

Brown, W.J. (1950) The extralimital distribution of some species of Coleoptera. The Canadian Entomologist, 82, 197205.

Brown, W.J. (1967) Notes on the extralimital distribution of some species of Coleoptera. The Canadian Entomologist, 99, 85-93.

Bousquet, Y. (1990) Beetles associated with stored products in Canada: an identification guide. Agriculture Canada Research Branch, Ottawa, Ontario. Publication 1837, 1-215.

Bousquet, Y. (1991a) Family Dermestidae: dermestid beetles. In Bousquet, Y. (Ed.) Checklist of Beetles of Canada and Alaska. Agriculture Canada Publication 1861/E. Ottawa, Ontario, pp. 196-199.

Bousquet, Y. (1991b) Family Ptinidae: spider beetles. In Bousquet, Y. (Ed.) Checklist of Beetles of Canada and Alaska. Agriculture Canada Publication 1861/E. Ottawa, Ontario, pp. 205-206.

Brown, W.J. (1940) A key to the species of Ptinidae occurring in dwellings and warehouses in Canada (Coleoptera). The Canadian Entomologist, 72, 115-122. 
Chandler, D.S. (2001) University of New Hampshire Insect and Arachnid Collections. Available from http://insectcoll.unh.edu/ (accessed 4 June 2007).

Clark, R.C. \& Brown, N.R. (1960) Studies of the Balsam Wooly Aphid, Adelges piceae (Ratz.) (Homoptera: Adelgidae). VII Laricobius rubidus Lec. (Coleoptera: Derodontidae), a predator of Pineus strobi (Htg.) (Homoptera: Adelgidae). The Canadian Entomologist, 92, 237-240.

Dearborn, R.G. \& Donahue, C.P. (1993) An annotated list of insects collected and recorded by the Maine Forest Service: Order Coleoptera, Beetles. Maine Forest Service, Technical Report 32. August, Maine, 101 pp.

Downie, N.M. \& Arnett, R.H., Jr. (1996) The beetles of northeastern North America. Sandhill Crane Press, Gainesville, Florida. $1721 \mathrm{pp}$.

Essig, E.O. (1926) Insects of Western North America. MacMillan Co., New York, New York. 1035 pp.

Evenhuis, N.L. (2007) Abbreviations for insect and spider collections of the world. Available from: http://hbs.bishopmuseum.org/codens/codens-inst.html (accessed 4 June 2007).

Fall, H.C. (1905) Revision of the Ptinidae [including Anobiidae] of Boreal America. Transactions of the American Entomological Society, 31, 97-296.

Fauvel, A. (1889) Liste des coléoptères communs à l'Europe et à l'Amérique du Nord [et premier supplement]. Revue entomologique, 8, 92-174.

Fisher, W.S. (1950) A revision of the North American species of beetles belonging to the family Bostrichidae. Miscellaneous Publications of the United States Department of Agriculture, no. 698, $157 \mathrm{pp}$.

Gerberg, E.J. (1957) A revision of the New Word species of powder-post beetles belonging to the family Lycidae. United States Department of Agriculture, Technical Bulletin, 1157, 1-55.

Hatch, M.H. (1962) Beetles of the Pacific Northwest, Part III. Dermestidae, pp 278-293. University of Washington Press, Seattle, Washington.

Howe, R.W. (1957) A laboratory study of the cigarette beetle, Lasioderma serricorne (F.) (Col., Anobiidae) with a critical review of the literature on its biology. Bulletin of Entomological Research, 48, 9-56.

Howe, R.W. \& Burges, H.D. (1951) Studies on beetles of the family Ptinidae: VI. The biology of Ptinus fur (L.) and P. sexpunctatus Panzer. Bulletin Entomological Research, 42, 499-511.

Ivie, M.A. (2002) Bostrichidae Latreille 1802. In: Arnett, R.H., Jr., Thomas, M.C., Skelley, P.E. \& Frank, J.H. (Eds.). American Beetles, Volume 2: Polyphaga: Scarabaeoidea through Curculionoidea. CRC Press, Boca Raton, USA, pp. 233-244.

Joly, L.J., Dedordy, J., \& Moreira, M. (1994) Sinoxylon anale Lesne, 1897 (Coleoptera, Bostrichidae) nuevo registro para la fauna Venezolana. Boletin de Entomologa Venezolana. N.S., 9, 21-24.

Jones, J. M. (1869) Nova Scotia Coleoptera: Part I. Transactions of the Nova Scotia Institute of Natural Science, 2, 141155.

Kingsolver, J.M. (2002) Dermestidae Gyllenhal 1808. In: Arnett, R.H., Jr., Thomas, M.C., Skelley, P.E. \& Frank, J.H. (Eds.). American Beetles, Volume 2: Polyphaga: Scarabaeoidea through Curculionoidea. CRC Press, Boca Raton, USA. pp. 228-232.

Kirby, W. (1837) Fauna boreali-Americana or the Zoology of the northern parts of British America, containing descriptions of the objects of natural history collected on the late northern land expeditions, under the command of Captain Sir John Franklin, RN, by John Richardson. Volume 4. Fletcher, Norwich, England, 325 pp.

Koehler, P.G. (1999) Lesser Grain Borer, Rhyzopertha dominica (Coleoptera, Bostrichidae). Florida Cooperative Extension Service, Institute of Food and Agricultural Sciences, University of Florida. Document ENY-264. Available from http://edis.ifas.ufl.edu/IG117 (accessed 4 June 2007).

LeConte, J.L. (1865) Prodromus of a monograph of the species of the tribe Anobiini, of the family Ptinidae, inhabiting North America. Proceedings of the Academy of Natural Sciences of Philadelphia, 17, 222-244.

Leschen, R.A.B. (2002) Derodontidae LeConte 1861. In: Arnett, R.H., Jr., Thomas, M.C., Skelley, P.E. \& Frank, J.H. (Eds.). American Beetles, Volume 2: Polyphaga: Scarabaeoidea through Curculionoidea. CRC Press, Boca Raton, USA, pp. 221-223.

Lindroth, C.H. (1957) The faunal connections between Europe and North America. Almqvist and Wiksell, Stockholm, Sweden, $344 \mathrm{pp}$.

Loo, J. \& Ives, N. (2003) The Acadian forest: historical condition and human impacts. The Forestry Chronicle, 79, 462472.

Majka, C.G. (2006) The Mycteridae, Boridae, Pythidae, Pyrochroidae, and Salpingidae (Coleoptera: Tenebrionoidea) of the Maritime Provinces of Canada. Zootaxa, 1250, 37-51.

Majka, C.G., Anderson, R.S., \& McCorquodale, D.B. (2007a) The weevils of the Maritime Provinces of Canada, II: new records from Nova Scotia and Prince Edward Island and regional zoogeography (Coleoptera: Curculionoidea). The Canadian Entomologist, 139, 397-442.

Majka, C.G., Cook, J., \& Westby, S. (2006) Introduced Carabidae (Coleoptera) from Nova Scotia and Prince Edward Island: new records and ecological perspectives. The Canadian Entomologist, 138, 602-609.

Majka, C.G. \& McCorquodale, D.B. (2006) The Coccinellidae (Coleoptera) of the Maritime Provinces of Canada: new 
records, biogeographic notes, and conservation concerns. Zootaxa, 1154, 49-68.

Majka, C.G., Philips, T.K., \& Sheffield, C.S. (2007b) Ptinus sexpunctatus Panzer (Coleoptera: Anobiidae: Ptininae) newly recorded in North America. Entomological News, 118(1), 73-76.

Majka, C.G. \& Pollock, D.A. (2006) Understanding saproxylic beetles: new records of Tetratomidae, Melandryidae, Synchroidae, and Scraptiidae from the Maritime Provinces of Canada (Coleoptera: Tenebrionoidea). Zootaxa, 1248, 4568.

McMahon, J. (1989) The new forest in Nova Scotia. In Schneider, A. (Ed.) Deforestation and development in Canada and the tropics. University College of Cape Breton, Sydney, Nova Scotia, pp. 159-162.

McNamara, J. (1991a) Family Bostrichidae: bostrichid powder-post beetles. In Bousquet, Y. (Ed.) Checklist of Beetles of Canada and Alaska. Agriculture Canada Publication 1861/E. Ottawa, Ontario, pp. 199-200.

McNamara, J. (1991b) Family Lyctidae: lyctid powder-post beetles. In Bousquet, Y. (Ed.) Checklist of Beetles of Canada and Alaska. Agriculture Canada Publication 1861/E. Ottawa, Ontario, pp. 201.

McNamara, J. (1991c) Family Anobiidae: deathwatch beetles. In Bousquet, Y. (Ed.) Checklist of Beetles of Canada and Alaska. Agriculture Canada Publication 1861/E. Ottawa, Ontario, pp. 201-205.

Melsheimer, F.E. (1846) Descriptions of new species of Coleoptera of the United States. Proceedings of the Academy of Natural Sciences of Philadelphia, 2, 302-318.

Mertins, J.W. (1981) Life history and morphology of the odd beetle, Thylodrias contractus. Annals of the Entomological Society of America, 74, 576-581.

Noya D.R. \& Velez R.M. (1998) Nuevo Registro para Mexico de Trogoderma ornatum (Say) (Coleoptera: Dermestidae) Asociado Noc Apis mellifera L. (Hymenoptera: Apidae). Acta Zoologica Mexicana, 75, 195-197.

Peters, B.C., King, J. \& Wylie, F.R. (1996) Pests of Timber in Queensland. Queensland Forestry Research Institute, Department of Primary Industries, Brisbane, $175 \mathrm{pp}$.

Philips, T.K. (2002) Anobiidae Fleming 1821. In: Arnett, R.H., Jr., Thomas, M.C., Skelley, P.E. \& Frank, J.H. (Eds.). American Beetles, Volume 2: Polyphaga: Scarabaeoidea through Curculionoidea. CRC Press, Boca Raton, USA, pp. 245-260.

Potter, C. (1935) The biology and distribution of Rhizopertha dominica (Fab.). Transactions of the Royal Entomological Society of London, 83, 449-482.

Prévost, M.-A, \& Bain, A. (2006) L'implantation d'une colonie terre-neuvienne au XVIIe siècle: l'apport des analyses archéobotanique et archéoentomologique. In: Bain, A., Chabot, J. \& Moussette, M. (Eds.). La mesure du pass: contributions la recherche en archomtrie (2000-2006). British Archaeological Reports. (in press)

Say, T. (1825) Descriptions of new species of coleopterous insects inhabiting the United States. Journal of the Academy of Natural Sciences of Philadelphia, 5(1), 160-204.

Sikes, D.S. (2004) The beetle fauna of Rhode Island: an annotated checklist. Rhode Island Natural History Survey, Volume 3. Kingston, Rhode Island, 296 pp.

Slosson, A.T. (1903) A coleopterous conundrum. The Canadian Entomologist, 35, 183-187.

Spillman, T.J. (1982) False powderpost beetles of the genus Dinoderus in North America (Coleoptera, Bostrichidae). The Coleopterists Bulletin, 36(2), 193-196.

White, R.E. (1975) Lasioderma haemorrhoidale (Ill.) now established in California, with biological data on Lasioderma species (Coleoptera: Anobiidae). The Coleopterists Bulletin, 44(3), 344-348.

White, R.E. (1982) A catalogue of the Coleoptera of America north of Mexico, Family Anobiidae. United States Department of Agriculture, Agricultural Research Service, Agricultural Handbook 529-70.

Woodroffe, G.E. \& Southgate, B.J. (1954) An investigation of the distribution and field habits of the varied carpet beetle, Anthrenus verbasci (L.) (Col. Dermestidae) in Britain, with comparative notes on A. fuscus Ol. and A. museorum (L.). Bulletin of Entomological Research, 45, 575-583.

Wright, C.G. (1960) Biology of the Southern Lyctus Beetle, Lyctus planicollis. Annals of the Entomological Society of America, 53, 285-292. 